\title{
Identification of Microglial Signal Transduction Pathways Mediating a Neurotoxic Response to Amyloidogenic Fragments of $\beta$-Amyloid and Prion Proteins
}

\author{
Colin K. Combs, Derrick E. Johnson, Steve B. Cannady, Timothy M. Lehman, and Gary E. Landreth \\ Alzheimer Research Laboratory, Departments of Neurology and Neurosciences, Case Western Reserve University School \\ of Medicine, Cleveland, Ohio 44106-4928
}

\begin{abstract}
Microglial interaction with amyloid fibrils in the brains of Alzheimer's and prion disease patients results in the inflammatory activation of these cells. We observed that primary microglial cultures and the THP-1 monocytic cell line are stimulated by fibrillar $\beta$-amyloid and prion peptides to activate identical tyrosine kinase-dependent inflammatory signal transduction cascades. The tyrosine kinases Lyn and Syk are activated by the fibrillar peptides and initiate a signaling cascade resulting in a transient release of intracellular calcium that results in the activation of classical PKC and the recently described calciumsensitive tyrosine kinase PYK2. Activation of the MAP kinases ERK1 and ERK2 follows as a subsequent downstream signaling event. We demonstrate that PYK2 is positioned downstream of
\end{abstract}

Lyn, Syk, and PKC. PKC is a necessary intermediate required for ERK activation. Importantly, the signaling response elicited by $\beta$-amyloid and prion fibrils leads to the production of neurotoxic products. We have demonstrated in a tissue culture model that conditioned media from $\beta$-amyloid- and prionstimulated microglia or from THP-1 monocytes are neurotoxic to mouse cortical neurons. This toxicity can be ameliorated by treating THP-1 cells with specific enzyme inhibitors that target various components of the signal transduction pathway linked to the inflammatory responses.

Key words: Alzheimer's disease; $\beta$-amyloid; prion; microglia; THP-1 monocytes; signal transduction; tyrosine kinase; inflammation; neurotoxicity
A subset of neurodegenerative diseases is linked to the aberrant, extracellular deposition of fibrillar proteins collectively termed "amyloids." Amyloids are generated in a disease-specific manner from structurally unrelated proteins (Kisilevsky, 1997).

Alzheimer's disease (AD) is a neurodegenerative disorder characterized by progressive deposition of $\beta$-amyloid fibrils in the brain to form senile plaques (Braak and Braak, 1997). The amyloidogenic material is composed of $\beta$-amyloid peptides $(\beta \mathrm{A})$ that are proteolytically derived from the amyloid precursor protein (Kang et al., 1987; Haas et al., 1992; Koo and Squazzo, 1994; Turner et al., 1996). The plaques are associated with reactive microglia and astrocytes as well as dystrophic neurites (Itagaki et al., 1989; Miyazono et al., 1991; Cotman et al., 1996).

The prion disorders are neurodegenerative diseases characterized by the accumulation of a pathological form of the prion protein $\left(\mathrm{PrP}^{\mathrm{sc}}\right)$ (Prusiner, 1982; Kretzschmar et al., 1986; Borchelt et al., 1992; Stahl et al., 1993). $\operatorname{PrP}^{\mathrm{sc}}$ is characterized by its infectious nature, partial resistance to proteolysis, and the capacity to aggregate extracellularly in the brain and to deposit as amyloid plaques in a subset of prion disorders (Prusiner et al., 1984; Oesch et al., 1985). Plaque formation is correlated with the

\footnotetext{
Received Aug. 3, 1998; revised Sept. 21, 1998; accepted Nov. 18, 1998.

This work was supported by National Institute on Aging Grant AG08012. C.K.C. was supported by National Institutes of Health Training Grant HD0710422. We thank Drs. Kurt Brunden and Gianluigi Forloni for their gifts of scrambled $\beta$ A 25-35 and PrP 106-126 peptides, respectively. Dr. Fred DeBeer kindly provided us with acetylated LDL. We thank Drs. George Dubyak and Ben Humphreys for their assistance in intracellular calcium measurements and for helpful comments. We also thank Dr. David Friel for useful discussion concerning intracellular calcium regulation.

Correspondence should be addressed to Dr. Gary Landreth, Alzheimer Research Laboratory, E 504, Case Western Reserve University, School of Medicine, 10900 Euclid Avenue, Cleveland, OH 44106-4928.

Copyright (C) 1999 Society for Neuroscience $\quad 0270-6474 / 99 / 190928-12 \$ 05.00 / 0$
}

appearance of reactive astrocytes and microglia as well as vacuolar cell loss (Miyazono et al., 1991; Guiroy et al., 1994; Jeffrey et al., 1994; Williams et al., 1994, 1997; Muhleisen et al., 1995; Betmouni et al., 1996; Brown and Kretzschmar, 1997; Kretzschmar et al., 1997).

Both types of fibrillar amyloid deposits share an invariant association with reactive glial cells, particularly microglia. There is abundant evidence of a microglial-derived inflammatory component in either disease. Microglia associated with amyloid plaques exhibit elevated expression of several cell surface markers indicative of a reactive state (McGeer et al., 1993; McGeer and McGeer, 1995). A variety of acute-phase proinflammatory proteins are also associated with the amyloid plaques (McGeer and Rogers, 1992; McGeer and McGeer, 1995). Moreover, several in vitro studies have now documented the ability of fibrillar $\beta \mathrm{A}$ and PrP peptides to induce microglial secretion of cytokines and neurotoxic reactive oxygen species (Forloni et al., 1993; Brown et al., 1996; Ii et al., 1996; Klegeris and McGeer, 1997; Klegeris et al., 1997; Kretzschmar et al., 1997; Lorton, 1997; McDonald et al., 1997). Consequently, maintained microglial contact with amyloid plaques could serve to initiate localized inflammatory responses in diseased brains.

We have identified a tyrosine kinase-based signaling cascade in microglial lineage cells that is activated by exposure of the cells to both $\beta \mathrm{A}$ and PrP fibrils and is directly responsible for the production of neurotoxic factor(s) by the activated cells. These intracellular signaling pathways are common to those used by these cells in response to classical inflammatory stimuli (Ghazizadeh et al., 1994, 1995; Marcilla et al., 1995; Crowley et al., 1997; Vonakis et al., 1997). We demonstrate that specific inhibition of enzymes within the activation pathway prevents the acquisition of 
a reactive, neurotoxic phenotype and offers novel interventive strategies.

\section{MATERIALS AND METHODS}

Materials. The anti-phosphotyrosine antibody 4G10 was from Upstate Biotechnology (Lake Placid, NY). Anti-paxillin and anti-PYK2 antibodies were obtained from Santa Cruz Biotechnology (Santa Cruz, CA). Anti-phospho-ERK and anti-ERK antibodies were purchased from Promega (Madison, WI) and Santa Cruz Biotechnology, respectively. The anti-MAP2 antibody was from Sigma (St. Louis, MO). The anti-Fc ${ }_{\gamma} R_{I I}$ antibody (monoclonal antibody IV.3) was obtained from Medarex (Annendale, NJ). Goat anti-mouse $\mathrm{F}(\mathrm{ab})_{2}$ was obtained from Cappel (West Chester, PA). Affinity-purified horseradish peroxidase-conjugated goat anti-mouse and goat anti-rabbit antibodies were purchased from Boehringer Mannheim (Indianapolis, IN). Peptides corresponding to amino acids $25-35$ and $1-40$ of human $\beta$-amyloid protein and amino acids 106-126 of human prion protein were purchased from Bachem (Philadelphia, PA). Scrambled $\beta$-amyloid $25-35$ peptide was synthesized at Gliatech (Cleveland, $\mathrm{OH})$. Scrambled prion peptide was a generous gift from Dr. Gianluigi Forloni (Milano, Italy). $\beta$-Amyloid peptides were resuspended in sterile $\mathrm{dH}_{2} \mathrm{O}$, and prion peptides were dissolved in sterile $200 \mathrm{~mm}$ sodium phosphate buffer, $\mathrm{pH}$ 7.0. Fibrillar $\beta$-amyloid $1-40$ was prepared by reconstitution of the lyophilized peptide in sterile distilled water, followed by incubation for 1 week at $37^{\circ} \mathrm{C}$. Acetylated low-density lipoprotein (LDL) was a kind gift from Dr. Frederick DeBeer (University of Kentucky). Lipopolysaccharide (LPS), nitroblue tetrazolium, 12-otetradecanoylphorbol 13-acetate (TPA), glycated BSA, dantrolene, verapamil, nifedipine, and concanavalin A (Con A) were purchased from Sigma. Piceatannol was purchased from Boehringer Mannheim. Go6976 was purchased from LC Laboratories. 2,5-Di-tert-butyl hydroquinone (DTBHQ), thapsigargin, BAPTA, and PP1 were purchased from Calbiochem (La Jolla, CA).

Tissue culture. THP-1 cells were grown in RPMI 1640 (BioWhittaker, Walkersville, MD) supplemented with $10 \%$ heat-inactivated fetal calf serum (FCS), $5 \times 10^{-5}$ м 2-mercaptoethanol, $5 \mathrm{~mm}$ HEPES, and 2 $\mu \mathrm{g} / \mathrm{ml}$ gentamycin in $5 \% \mathrm{CO}_{2}$. Microglial cultures were derived from postnatal day 1-2 mouse brain as described previously (McDonald et al., 1997). Neurons were cultured from cortices of embryonic day 17 (E17) mice $(\mathrm{C} 57 \mathrm{Bl} / 6 \mathrm{~J})$. Meninges-free cortices were isolated and digested in $0.25 \%$ trypsin and $1 \mathrm{~mm}$ EDTA for $15 \mathrm{~min}$ at $37^{\circ} \mathrm{C}$. The trypsin was inactivated with DMEM containing $20 \%$ heat-inactivated FCS. Cortices were transferred to Neurobasal media with B27 supplements, triturated, and plated onto poly-L-lysine $(0.05 \mathrm{mg} / \mathrm{ml})$-coated tissue culture wells. Neurons were grown in Neurobasal media $\left(4.0 \times 10^{4}\right.$ neurons/well) with B27 supplement for 5-7 d in vitro before use. The use of Neurobasal medium provided highly purified cultures of neurons to decrease the confound of contaminating glial cells in the cultures (Brewer et al., 1993).

Cell stimulation. THP-1 cells and microglia were stimulated by first removing their respective medium and replacing it with HBSS for $30 \mathrm{~min}$ at $37^{\circ} \mathrm{C}$ before stimulation. Cells were stimulated in suspension $(5-10 \times$ $10^{6}$ cells $/ 200 \mu \mathrm{l}$ of HBSS). To determine the effects of specific enzyme inhibition on $\beta \mathrm{A}$ and PrP stimulation of the THP-1 cells, we preincubated the cells for $45 \mathrm{~min}$ in the absence or presence of the drugs. To condition media, we plated THP-1 cells onto peptides bound ( 48 pmole/ $\mathrm{mm}^{2}$ ) to 48 well tissue culture dishes as described previously (Lagenaur and Lemmon, 1987; McDonald et al., 1997). Briefly, tissue culture wells were coated with nitrocellulose, and peptides were added to the coated wells and allowed to dry. The wells were then incubated with sterile $3 \%$ BSA in $\mathrm{dH}_{2} \mathrm{O}$ for $1 \mathrm{hr}$ to block cellular interactions with nitrocellulose. The BSA was removed, and THP- 1 cells were added $\left(1.8 \times 10^{4}\right.$ cells $)$ to wells containing the bound peptides in $0.25 \mathrm{ml}$ of Neurobasal media for $48 \mathrm{hr}$ in the presence or absence of drugs. The media were collected and then added to neuronal cultures for $72 \mathrm{hr}$. Microglial-mediated neuronal toxicity experiments involved the coculture of microglia $\left(1.8 \times 10^{4}\right.$ cells $)$ added directly to neuronal cultures $\left(4.0 \times 10^{4}\right.$ cells $)$ for $48 \mathrm{hr}$ in the absence or presence of $1 \mu \mathrm{M} \beta \mathrm{A} 25-35$. Neurons were fixed and stained with an anti-MAP2 (1:500) antibody. All conditions were performed in duplicate and repeated a total of four times. A counting grid was placed over the wells to count the number of neurons from eight identical fields for each condition. The average number of neurons per field was calculated for each condition to evaluate neuron survival.

Western blotting and immunoprecipitations. Cells were lysed in $200 \mu \mathrm{l}$ of ice-cold radioimmunoprecipitation assay (RIPA) buffer (1\% Triton, $0.1 \%$ SDS, $0.5 \%$ deoxycholate, $20 \mathrm{~mm}$ Tris, $\mathrm{pH} 7.4,150 \mathrm{~mm} \mathrm{NaCl}, 10 \mathrm{~mm}$ $\mathrm{NaF}, 1 \mathrm{~mm} \mathrm{Na} \mathrm{VO}_{4}, 1 \mathrm{~mm}$ EDTA, 1 mm EGTA, and $0.2 \mathrm{M}$ PMSF), and insoluble material was removed by centrifugation at $10,000 \times g$ at $4^{\circ} \mathrm{C}$ for $10 \mathrm{~min}$. Protein concentrations were quantitated by the method of Bradford (1976). Proteins were resolved by 7.5\% SDS-PAGE and Western blotted with primary antibody [4G10 (1:2000); anti-phospho-ERK (1: 20,000); anti-ERK (1:2000); anti-PYK2 (1:1000); anti-paxillin (1:5000)] overnight at $4{ }^{\circ} \mathrm{C}$. Antibody binding was detected via enhanced chemiluminescence (Pierce, Rockford, IL). To reprobe blots, we stripped them using $0.2 \mathrm{~N} \mathrm{NaOH}$ with vigorous shaking for $10 \mathrm{~min}$ at $25^{\circ} \mathrm{C}$ (Suck and Krupinska, 1996). Immunoprecipitations were performed by incubation of aliquots of the cellular lysates with the primary antibody $(1 \mu \mathrm{g}$ of antibody $/ \mathrm{mg}$ of protein lysate) and Protein A-agarose for $2 \mathrm{hr}$ at $4^{\circ} \mathrm{C}$. The immunoprecipitates were washed three times in RIPA buffer, then resolved by $7.5 \%$ SDS-PAGE, and Western blotted as described.

Respiratory burst. Intracellular superoxide production was assayed as described by measuring the reduction of nitroblue tetrazolium (NBT) (Pick, 1986; McDonald et al., 1997). Briefly, THP-1 cells $\left(2.0 \times 10^{6}\right.$ cells per condition) were removed from media and allowed to incubate in HBSS for $30 \mathrm{~min}$ at $37^{\circ} \mathrm{C}$ with or without drugs $(5 \mu \mathrm{M}$ PP1, $50 \mathrm{~nm}$ thapsigargin, or $2 \mu \mathrm{M}$ Go6976) or vehicle (DMSO). Cells were removed from HBSS, resuspended in HBSS containing $1 \mu \mathrm{g} / \mathrm{ml} \mathrm{NBT}$, and incubated for $30 \mathrm{~min}$. Cells were then collected by centrifugation and sonicated in RIPA buffer to collect the NBT precipitates. Reduction of NBT was measured by the change in absorbance at $550 \mathrm{~nm}$. The assays were performed in duplicate.

Cytosolic free-calcium measurement. $\left[\mathrm{Ca}^{2+}\right]$ was measured in THP-1 cells using the fluorescent indicator fura- 2 in a thermostatically controlled luminometer with magnetic stirring as described by El-Moatassim and Dubyak (1992). Calcium concentrations were calculated based on the method of Di Virgilio et al. (1988).

\section{RESULTS}

\section{$\beta A$ and PrP fibrils activate a similar tyrosine kinase- based signaling pathway in microglia and THP-1 monocytes}

Exposure of both primary mouse microglia and THP-1 cells to fibrillar PrP 106-126 and $\beta$ A 25-35 activated a tyrosine kinasebased intracellular signaling cascade in both THP-1 cells (Fig. $1 A$ ) and microglia (Fig. $1 B$ ). Full-length $\beta A$ 1-40 and 1-42 peptides initiated intracellular signaling events, and the biologically active domain was mapped to residues 25-35 (Fig. 1A) (McDonald et al., 1997). Similarly, we used the biologically active domain of human prion protein comprising residues 106-126. This domain is essential for the conversion of $\operatorname{PrP}^{\mathrm{c}}$ to $\mathrm{PrP}^{\mathrm{sc}}$ and forms amyloid fibrils in vitro (Gasset et al., 1992; Selvaggini et al., 1993; Tagliavanni et al., 1993; Chen et al., 1995). The cellular stimulation is specific to the fibrillar conformation of the peptides because scrambled, nonfibrillar forms of PrP 106-126 and $\beta \mathrm{A}$ 25-35 did not elicit any increase in protein tyrosine phosphorylation levels (Fig. 1A). This response was not mediated by the receptor for advanced glycation end products (RAGE) or scavenger receptors because ligands for these receptors (glycated BSA and acetylated LDL, respectively) did not alter protein tyrosine phosphorylation levels (Fig. $1 A$ ). The pattern of protein tyrosine phosphorylation elicited by the $\beta \mathrm{A}$ and $\mathrm{PrP}$ peptides was qualitatively similar; however, the relative phosphotyrosine content of the individual proteins varied between experiments (Fig. $1 C)$. The fibril-stimulated protein tyrosine phosphorylation results in the phosphorylation of a number of proteins that are also phosphorylated after activation of classical immune receptors such as $\mathrm{Fc}_{\gamma} \mathrm{R}_{\mathrm{II}}$ (Fig. $1 C$ ). THP-1 cells were typically stimulated by adding fibrillar PrP 106-126 and $\beta$ A 25-35 directly to the cells in solution. However, stimulation of protein tyrosine phosphorylation was also observed when the THP-1 cells were plated directly onto fibrillar peptides bound to tissue culture wells (data not shown) (McDonald et al., 1997, 1998).

The persistent exposure of THP-1 cells and primary mouse microglia to $\beta \mathrm{A} 25-35$ (Fig. $2 B, E$, respectively) and $\operatorname{PrP} 106-126$ 
A

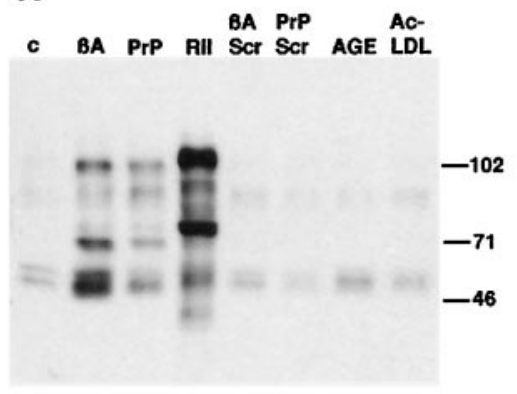

C

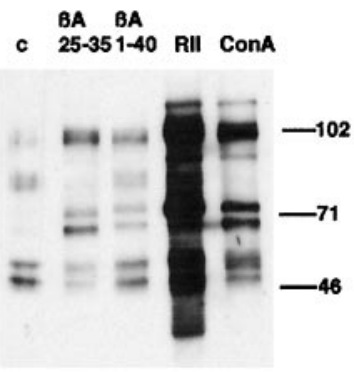

Figure 1. $\quad \beta A$ and $\operatorname{Pr} P$ fibrils specifically activate tyrosine kinase signaling pathways in microglia and THP-1 monocytes. $A$, Protein phosphotyrosine levels were evaluated in THP-1 cells after stimulation with $\operatorname{Pr} P, \beta A$, scrambled $\beta A(S c r \beta A)$ 25-35 (40 $\mu \mathrm{M} ; 2$ min), scrambled $\operatorname{Pr} P(\operatorname{Scr} \operatorname{Pr} P)$ $106-126(80 \mu \mathrm{M} ; 5 \mathrm{~min}), 20 \mu \mathrm{g} / \mathrm{ml}$ glycated BSA $+20 \mu \mathrm{g} / \mathrm{ml}$ lactoferrin $(A G E)\left(2 \mathrm{~min} ; 37^{\circ} \mathrm{C}\right)$, or $20 \mu \mathrm{g} / \mathrm{ml}$ acetylated LDL $(A c-L D L)(2 \mathrm{~min}$; $37^{\circ} \mathrm{C}$ ). $B$, Protein phosphotyrosine levels were compared in primary mouse microglia stimulated in solution with the fibrillar peptides $\operatorname{Pr} P$ $106-126$ or $\beta A 25-35$ or with $60 \mu \mathrm{g} / \mathrm{ml}$ concanavalin A (ConA) to serve as a positive control. $C$, Protein tyrosine phosphorylation changes were compared when THP-1 cells were stimulated with full-length fibrillar $\beta A$ 1-40 peptide, $\beta A 25-35$ peptide, or positive controls cross-linking of $\mathrm{Fc}_{\gamma} \mathrm{R}_{\mathrm{II}}\left[25 \mu \mathrm{g} / \mathrm{ml}\right.$ anti-Fc $\mathrm{F}_{\gamma} \mathrm{R}_{\mathrm{II}}$ antibody $(\mathrm{Ab})+100 \mu \mathrm{g} / \mathrm{ml} \mathrm{G} \alpha \mathrm{M}$ $\mathrm{Fab}_{2}\left(15\right.$ min on ice with $\mathrm{Ab}+2$ min at $37^{\circ} \mathrm{C}$ with $\left.\left.\mathrm{Fab}_{2}\right)\right]$ and $\mathrm{Con} \mathrm{A}$. Aliquots of the cell lysates were resolved by SDS-PAGE, Western blotted using the anti-phosphotyrosine antibody 4G10, and visualized by chemiluminescence.

(Fig. 2C,F respectively) fibrils for $48 \mathrm{hr}$ resulted in the elevation of phosphotyrosine immunoreactivity. These in vitro findings confirmed that sustained exposure of the cells to the fibrillar peptides evoked the prolonged activation of tyrosine kinasebased signaling events and functionally modeled the in vivo response of the plaque-associated microglia in the AD brain that exhibit high levels of phosphotyrosine (Wood and Zinsmeister, 1991).

\section{The tyrosine kinases Lyn and Syk regulate MAP kinase activation}

Lyn and Syk represent the principal catalytic components mediating the signaling response of cells of the monocytic lineage to immune stimuli (Ghazizadeh et al., 1994, 1995; Marcilla et al., 1995; Crowley et al., 1997; Vonakis et al., 1997). To test whether Lyn and Syk are involved as proximal elements in the signaling activation pathways stimulated by $\beta \mathrm{A}$ or $\mathrm{PrP}$, we treated cells with a specific inhibitor of src family kinases, PP1, to block Lyn activity (Hanke et al., 1996) or with the Syk-selective inhibitor piceatannol (Oliver et al., 1994) and evaluated their effects on the activation of downstream signaling elements. Pretreatment of the THP-1 cells with PP1 and piceatannol inhibited ERK activation in response to fibrillar PrP 106-126 and $\beta A$ 25-35 (Fig. 3B-D).
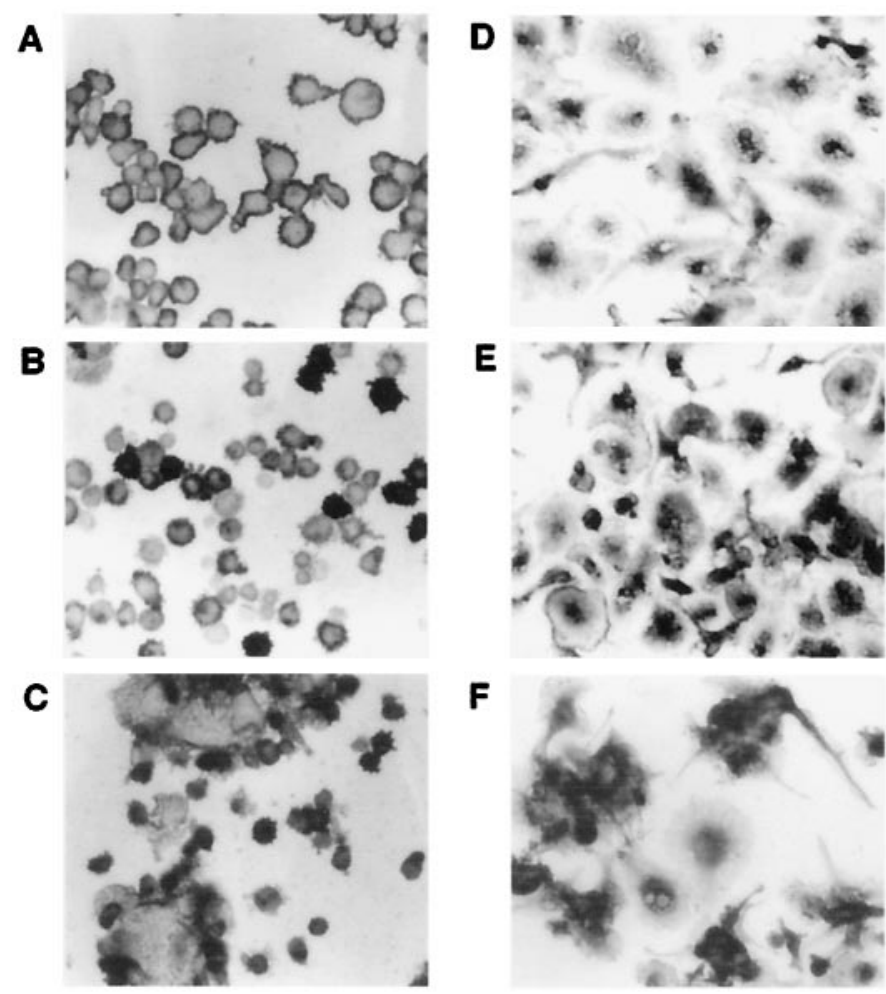

Figure 2. $\quad \beta \mathrm{A}$ and PrP fibril stimulation of THP-1 cells and microglia induces increased phosphotyrosine staining. Primary mouse microglia $(D-F)$ and THP-1 cells $(A-C)$ were plated onto uncoated dishes $(A, D)$ or dishes coated with $\beta$ A $25-35(B, E)$ or PrP 106-126 $(C, F)$ and cultured for $48 \mathrm{hr}$. Cells were fixed in $4 \%$ paraformaldehyde and stained with the anti-phosphotyrosine antibody 4G10. Immunoreactivity was visualized using 3,3'-diaminobenzidine tetrahydrochloride as the chromogen.

As controls, the fibril-stimulated increase in protein tyrosine phosphorylation was also monitored after blocking Lyn and Syk activation. Inhibition of Lyn activity prevented the fibril-activated increase in protein tyrosine phosphorylation (Fig. $3 E, F$ ). Inhibition of Syk activation produced only a partial decrease in the changes in protein tyrosine phosphorylation (Fig. $3 G$ ), consistent with a scheme in which Syk is recruited to the receptor complex for activation downstream of Lyn.

\section{$\beta A$ and PrP fibril stimulation of THP-1 cells elicits a transient increase in intracellular calcium levels released from intracellular stores}

Activation of monocyte immune receptor signaling pathways can involve an increase in intracellular calcium levels (Odin et al., 1991; Liao et al., 1992; Rankin et al., 1993; Shen et al., 1994). Moreover, it has been suggested that $\beta \mathrm{A}$ and PrP fibrils interact with cell membranes to alter specific calcium channel activities (Korotzer et al., 1995; Florio et al., 1996; Fraser et al., 1997; Herms et al., 1997; Lin et al., 1997).

We tested whether fibril stimulation of THP-1 cells altered levels of intracellular calcium. Fura-2-loaded THP-1 cells stimulated with either $\beta$ A $25-35$ or PrP 106-126 fibrils displayed a transient increase in intracellular calcium levels (Fig. $4 A, C$ ). The calcium was released from intracellular stores because elimination of extracellular calcium did not affect the fibril-stimulated increase in intracellular calcium levels (Fig. 4B,D). The depletion of extracellular calcium was confirmed by the inability of UTP to elicit an influx of calcium (data not shown). 


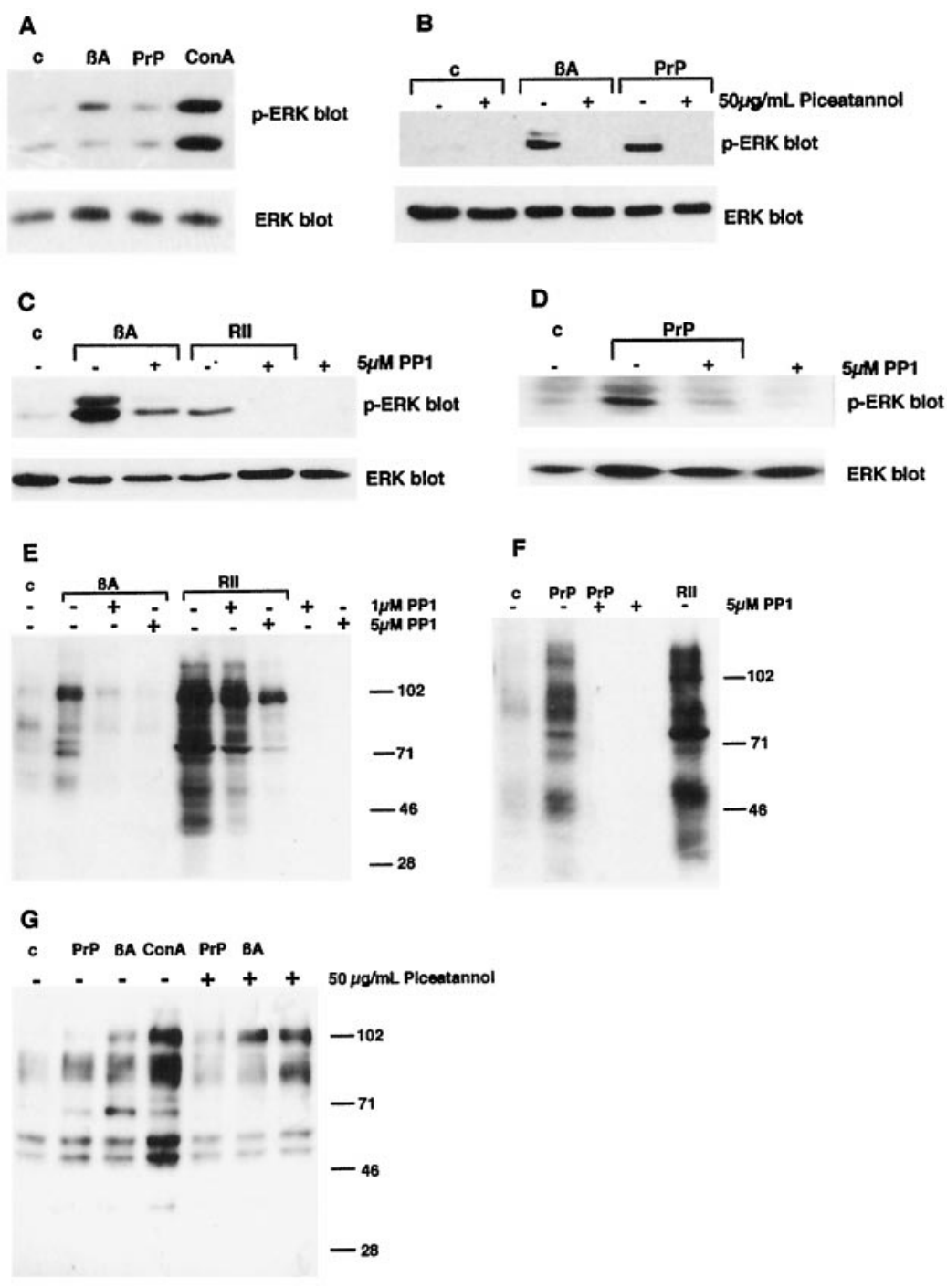

Figure 3. $\beta A$ and $\operatorname{PrP}$ fibril stimulation of THP-1 cells requires activation of the tyrosine kinases Lyn and Syk to activate the MAP kinases. THP-1 cells were incubated in DMSO vehicle $(c), 1$ or $5 \mu \mathrm{M} P P 1$, or $50 \mu \mathrm{g} / \mathrm{ml}$ piceatannol ( $45 \mathrm{~min} ; 37^{\circ} \mathrm{C}$ for each) before incubation in $\operatorname{PrP} 106-126$ (80 $\mu \mathrm{M} ; 5 \mathrm{~min})$ or $\beta A 25-35(40 \mu \mathrm{M} ; 2 \mathrm{~min})$ or cross-linking of $\mathrm{Fc}_{\gamma} \mathrm{R}_{\mathrm{II}}\left[25 \mu \mathrm{g} / \mathrm{ml}\right.$ anti-Fc $\mathrm{R}_{\gamma} \mathrm{RI}$ Ab $+100 \mu \mathrm{g} / \mathrm{ml} \mathrm{G} \alpha \mathrm{M} \mathrm{Fab}_{2}(15$ min on ice with $\mathrm{Ab}+2$ min at $37^{\circ} \mathrm{C}$ with $\left.\mathrm{Fab}_{2}\right)$ ] or Con $\mathrm{A}(60$ $\mu \mathrm{g} / \mathrm{ml} ; 5 \mathrm{~min}$ ) as a positive control. Aliquots of the cell lysates were resolved by SDS-PAGE, Western blotted, and visualized by chemiluminescence. An antibody directed against the activated, phosphorylated forms of ERK1 and ERK2 ( $p$ $E R K$ ) was used to monitor ERK activation. To normalize for protein load, we stripped the blots and reprobed them with anti-ERK antibody $(E R K)$. Primary mouse microglia were stimulated with $\operatorname{Pr} P, \beta A$, or Con $\mathrm{A}$, as described above. $A$, ERK phosphorylation was examined in primary mouse microglia stimulated with $\operatorname{Pr} P 106-126$ or $\beta A 25-35$. $B-D$, ERK phosphorylation and activation were also examined in THP-1 cells pretreated with $50 \mu \mathrm{g} / \mathrm{ml}$ piceatannol $(B)$ or $5 \mu \mathrm{M} P P 1$ $(C, D)$ before stimulation with $\operatorname{Pr} P 106-126$ and $\beta A$ 25-35. E, $F$, Changes in protein tyrosine phosphorylation levels were examined using the anti-phosphotyrosine $\mathrm{Ab} 4 \mathrm{G} 10$, when THP-1 cells were pretreated with 1 or $5 \mu \mathrm{M} P P 1$ before stimulation with $\beta A$ 25-35 (E) and $\operatorname{PrP} 106-126(F)$. $G$, Changes in protein tyrosine phosphorylation levels were also monitored when THP- 1 cells were pretreated with $50 \mu \mathrm{g} / \mathrm{ml}$ piceatannol before stimulation with $\beta A 25-35$ or $\operatorname{Pr} P$ $106-126$.

Monocyte immune receptor signaling pathways, such as those downstream of $\mathrm{Fc}_{\gamma} \mathrm{R}_{\mathrm{II}}$, involve an increase in intracellular calcium levels via activation of phospholipase $\mathrm{C}_{\gamma 1}\left(\mathrm{PLC}_{\gamma 1}\right)$ (Odin et al., 1991; Liao et al., 1992; Rankin et al., 1993; Shen et al., 1994). Importantly, the $\beta \mathrm{A}$ and PrP fibril stimulation of THP-1 cells did not involve the activation of $\mathrm{PLC}_{\gamma 1}$ and the subsequent $\mathrm{IP}_{3^{-}}$ mediated intracellular calcium release. Neither $\beta$ A nor PrP fibril stimulation led to the tyrosine phosphorylation and activation of PLC $_{\gamma 1}$, clearly demonstrating that these stimuli use pathways that are mechanistically distinct from those used by $\mathrm{Fc}_{\gamma} \mathrm{R}_{\mathrm{II}}$ stimulation (Fig. 4E).

\section{Intracellular calcium levels regulate the protein tyrosine phosphorylation of a subset of proteins}

To establish the linkage between the increase in intracellular calcium levels and the activation of the tyrosine kinase signaling cascade, we evaluated levels of protein tyrosine phosphorylation in fibril-stimulated THP-1 cell lysates after manipulating the levels of both extra- and intracellular calcium. First, we confirmed that no influx of extracellular calcium was required for activation of the tyrosine kinase-dependent signaling pathway during stimulation with PrP 106-126 and $\beta$ A 25-35 because stimulation of the THP-1 cells in calcium-free media had little affect on $\beta \mathrm{A}$ - and PrP-induced protein tyrosine phosphorylation changes (Fig. $5 A$ ).

Because there is some evidence that $\beta \mathrm{A}$ and $\operatorname{PrP}$ peptides interact with cell membranes and influence L-type calcium channel activity, we verified that calcium influx through L-type channels was not contributing to the changes in protein tyrosine phosphorylation levels (Korotzer et al., 1995; Florio et al., 1996; Fraser et al., 1997; Herms et al., 1997; Lin et al., 1997). Pretreatment of the cells with the specific L-type calcium channel antagonists verapamil and nifedipine had no affect on increased protein tyrosine phosphorylation after $\beta \mathrm{A}$ and PrP fibril stimulation (data not shown) (Carafoli, 1987; Palade et al., 1989). These data confirmed that extracellular calcium influx was not involved in tyrosine kinase activation by $\beta \mathrm{A}$ and PrP fibril stimulation.

We tested whether an increase in intracellular calcium levels was required for activation of a subset of the tyrosine kinase activities in response to the fibrillar peptides by depletion of the intracellular calcium stores and monitoring of the effect on fibrilinduced protein tyrosine phosphorylation changes. Western blot analysis of THP-1 cell lysates stimulated with $\beta \mathrm{A} 25-35$ or $\mathrm{PrP}$ 106-126 showed a decrease in tyrosine phosphorylation of several proteins after pretreatment with the calcium ATPase inhibitors DTBHQ and thapsigargin (Fig. 5B,C) (Charles et al., 1993; Khan et al., 1995). A similar decrease was observed when cells were pretreated with the ryanodine receptor inhibitor dantrolene as 
A

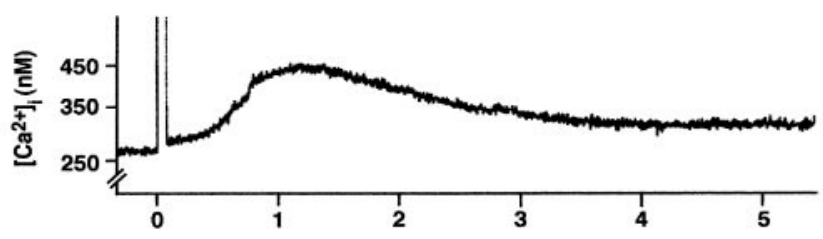

B

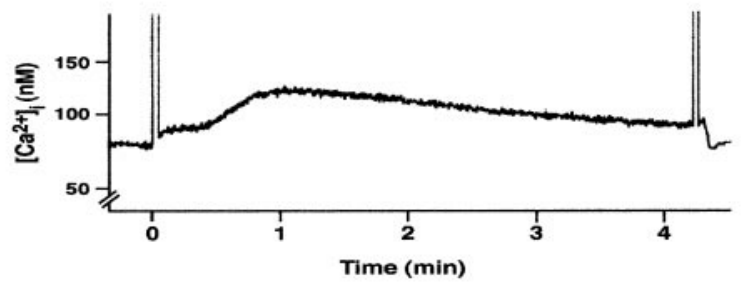

C

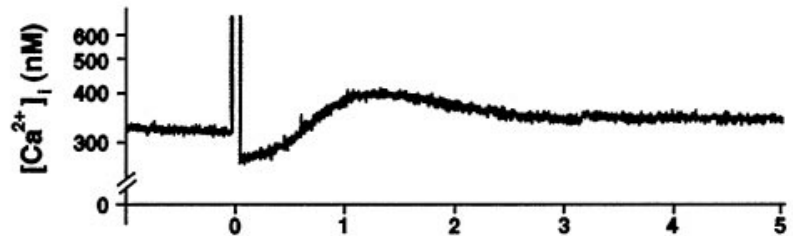

D

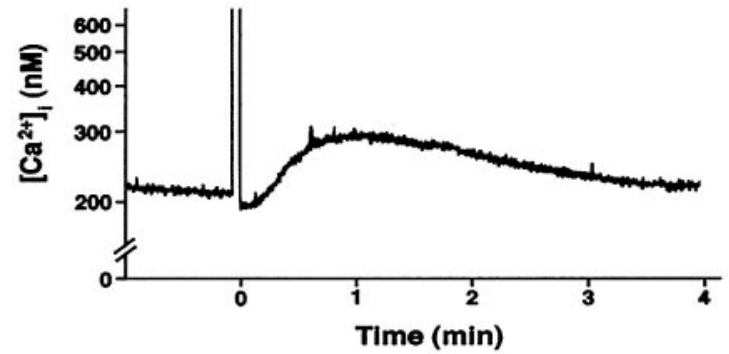

$\mathbf{E}$

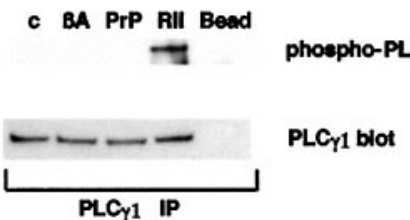

Figure 4. $\beta A$ and $\operatorname{PrP}$ fibril stimulation of THP-1 cells leads to the release of intracellular calcium. THP-1 cells were preloaded for $45 \mathrm{~min}$ with $0.5 \mathrm{~mm}$ fura- $2 \mathrm{AM}$, and basal levels of intracellular $\mathrm{Ca}$ were monitored for $3 \mathrm{~min}$. $A-D$, At time 0, cells were stimulated with $40 \mu \mathrm{M}$ $\beta$-amyloid $(A)$ or $80 \mu \mathrm{M} \operatorname{PrP} 106-126(C)\left(3.75 \times 10^{6}\right.$ cells/condition $)$ for $\sim 5 \mathrm{~min}$ in a calcium-containing or calcium-free balanced salt solution. The effect of removing extracellular calcium on $\beta A 25-35-(B)$ and $\operatorname{Pr} P$ 106-126-induced $(D)$ changes in intracellular calcium levels was compared. Data are representative of two independent experiments. $E, P L C_{\gamma 1}$ was immunoprecipitated from lysates of THP-1 cells stimulated with $\operatorname{Pr} P$ $106-126(80 \mu \mathrm{M} ; 5 \mathrm{~min})$ or $\beta A 25-35$ (40 $\mu \mathrm{M} ; 2 \mathrm{~min})$ or with cross-linking of $\mathrm{Fc}_{\gamma} \mathrm{R}_{\mathrm{II}}$ as a positive control $\left[25 \mu \mathrm{g} / \mathrm{ml}\right.$ anti-Fc $\mathrm{F}_{\gamma} \mathrm{R}_{\mathrm{II}} \mathrm{Ab}+100 \mu \mathrm{g} / \mathrm{ml}$ $\mathrm{G} \alpha \mathrm{M} \mathrm{Fab}_{2}$ (15 min on ice with $\mathrm{Ab}+2$ min at $37^{\circ} \mathrm{C}$ with $\left.\mathrm{Fab}_{2}\right)$ ]. Antibody specificities were verified by performing one immunoprecipitation $(I P)$ in the absence of the immunoprecipitating antibody (Bead). The antiphosphotyrosine antibody $4 \mathrm{G} 10$ was used to Western blot the immunoprecipitated protein. The blot was stripped and reprobed with the immunoprecipitating antibody to normalize for protein load.

well as the intracellular calcium chelator BAPTA (Fig. 5B,C) (Charles et al., 1993; Bissonnette et al., 1994). These data confirmed that the increase in protein tyrosine kinase activity stimulated by $\beta \mathrm{A}$ and PrP fibril stimulation was mediated, in part, by changes in intracellular calcium. To address this further, we induced a transient release of calcium from intracellular stores by
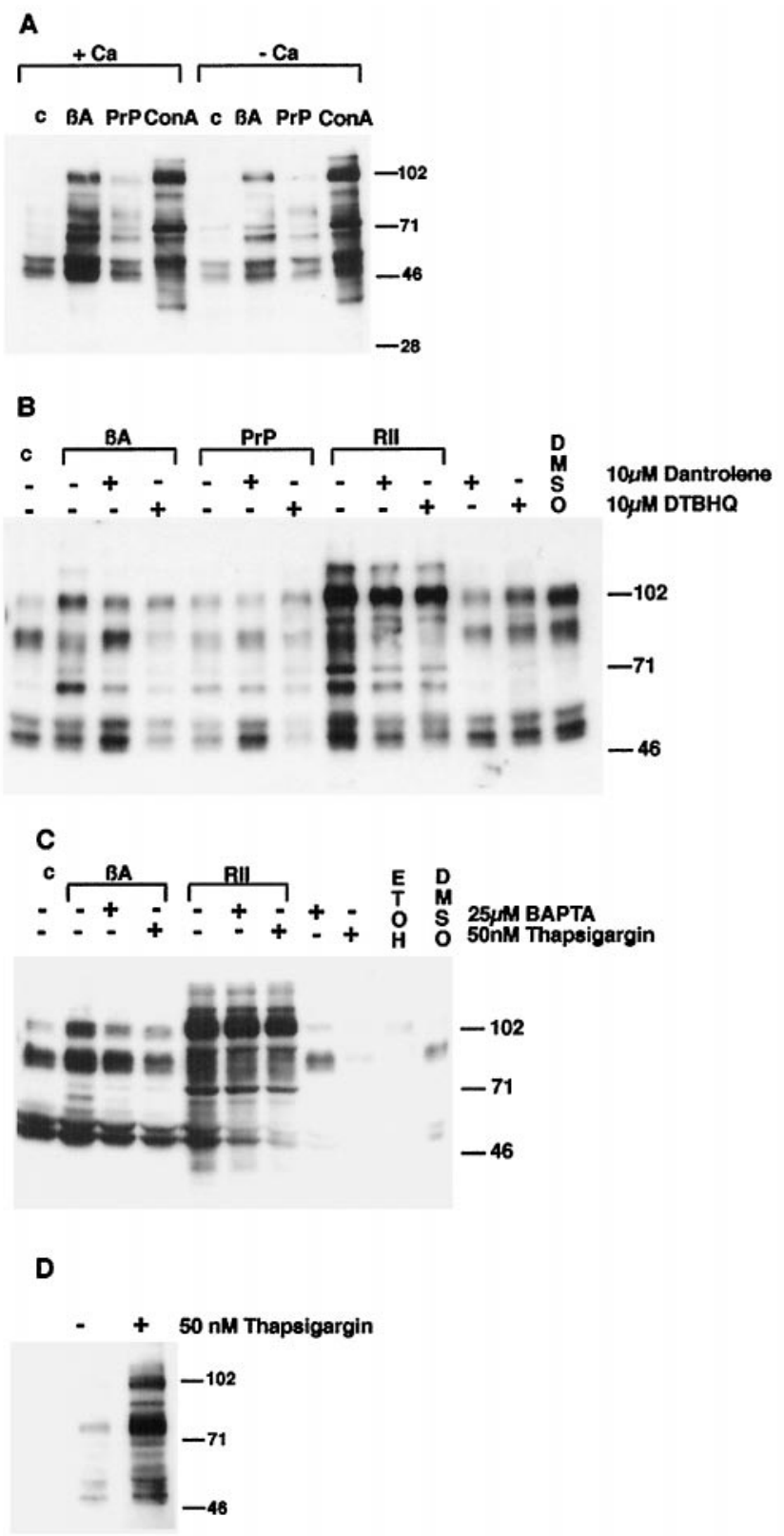

Figure 5. Release of intracellular calcium is required for specific tyrosine kinase activation during $\beta \mathrm{A}$ and PrP fibril stimulation of THP-1 cells. Aliquots of cell lysates were resolved by SDS-PAGE, Western blotted using the anti-phosphotyrosine antibody 4G10, and visualized by chemiluminescence. $A$, Protein phosphotyrosine levels were evaluated after THP-1 cells were stimulated with $\operatorname{PrP} 106-126$ (80 $\mu \mathrm{M} ; 5 \mathrm{~min})$, with $\beta A$ 25-35 (40 $\mu \mathrm{M} ; 2 \mathrm{~min})$, or with Con A $(60 \mu \mathrm{g} / \mathrm{ml} ; 5 \mathrm{~min})$ as a positive control in either calcium-containing HBSS $(+C a)$ or calcium-free HBSS containing 1 mm EDTA and 1 mm EGTA $(-C a)$. $B, C$, Protein phosphotyrosine levels were then compared when THP-1 cells were incubated in $D M S O$ vehicle (c), $10 \mu \mathrm{M} D T B H Q(B), 10 \mu \mathrm{M}$ dantrolene $(B), 25 \mu \mathrm{M}$ $B A P T A(C)$, or $50 \mathrm{~nm}$ thapsigargin $(C)\left(45 \mathrm{~min} ; 37^{\circ} \mathrm{C}\right.$ for each) before incubation in $\operatorname{PrP} 106-126$ (80 $\mu \mathrm{M} ; 5 \mathrm{~min})$ or $\beta A 25-35$ (40 $\mu \mathrm{M} ; 2 \mathrm{~min})$ or cross-linking of $\mathrm{Fc}_{\gamma} \mathrm{R}_{\mathrm{II}}$ as a positive control $\left[25 \mu \mathrm{g} / \mathrm{ml}\right.$ anti- $\mathrm{Fc}_{\gamma} \mathrm{R}_{\mathrm{II}} \mathrm{Ab}+$ $100 \mu \mathrm{g} / \mathrm{ml} \mathrm{G} \alpha \mathrm{M} \mathrm{Fab}_{2}\left(15 \mathrm{~min}\right.$ on ice with $\mathrm{Ab}+2 \mathrm{~min}$ at $37^{\circ} \mathrm{C}$ with $\left.\left.\mathrm{Fab}_{2}\right)\right]$. $D$, Protein phosphotyrosine changes were also examined when THP-1 cells were treated with $D M S O$ vehicle or $50 \mathrm{~nm}$ thapsigargin for $10 \mathrm{~min}$. 


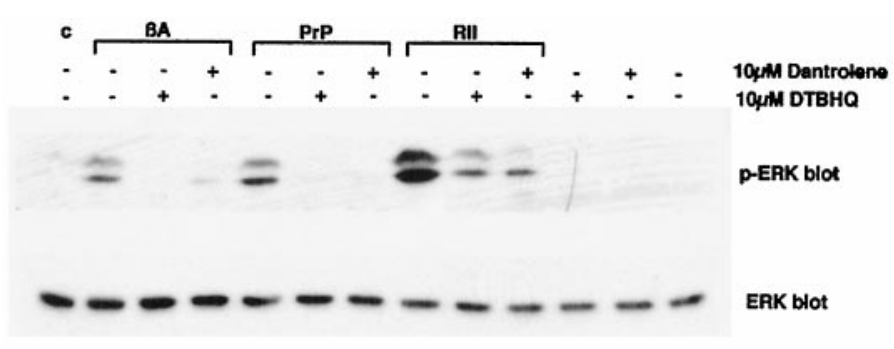

Figure 6. $\quad \beta A$ and $\operatorname{Pr} P$ fibril stimulation of MAP kinase activity in THP-1 cells requires an intracellular calcium release. THP-1 cells were incubated in DMSO vehicle $(c), 10 \mu \mathrm{M} \mathrm{DTBHQ}$, or $10 \mu \mathrm{M}$ dantrolene $\left(45 \mathrm{~min} ; 37^{\circ} \mathrm{C}\right.$ for each) before incubation in $\operatorname{PrP} 106-126$ (80 $\mu \mathrm{M}$; $5 \mathrm{~min}$ ) or $\beta A$ 25-35 (40 $\mu \mathrm{M} ; 2 \mathrm{~min}$ ) or cross-linking of $\mathrm{Fc}_{\gamma} \mathrm{R}_{\mathrm{II}}$ as a positive control $[25 \mu \mathrm{g} / \mathrm{ml}$ anti-Fc $\mathrm{R}_{\gamma} \mathrm{R}_{\mathrm{II}} \mathrm{Ab}+100 \mu \mathrm{g} / \mathrm{ml} \mathrm{G} \alpha \mathrm{M} \mathrm{Fab}_{2}$ (15 min on ice with $\mathrm{Ab}+2 \mathrm{~min}$ at $37^{\circ} \mathrm{C}$ with $\mathrm{Fab}_{2}$ )]. Aliquots of the cell lysates were resolved by SDSPAGE and Western blotted with an antibody directed against the activated, phosphorylated forms of ERK1 and ERK2 ( $p-E R K)$. Blots were stripped and reprobed with an anti-ERK antibody $(E R K)$ to normalize for protein load.

treatment of THP-1 cells with thapsigargin. Short periods of thapsigargin treatment elicited an increase in protein tyrosine phosphorylation, demonstrating that intracellular calcium levels regulate a subset of tyrosine kinase activities in THP-1 cells (Fig. 5D)

\section{MAP kinase activation in response to $\beta A$ and PrP fibril stimulation requires intracellular calcium}

The discovery of the fibril-stimulated elevation in intracellular calcium levels led us to investigate whether this was an obligatory intermediate step in signaling pathways leading to activation of the MAP kinases. Depletion of intracellular calcium stores with DTBHQ and dantrolene prevented the PrP 106-126- and $\beta A$ 25-35-induced activation of ERKs (Fig. 6). These data establish that the elevation in the concentration of intracellular calcium ion is necessary for the downstream activation of the MAP kinases.

\section{PKC activity is required for protein tyrosine phosphorylation and ERK activation in $\beta A$ and PrP fibril-stimulated THP-1 cells}

Classical PKC isoforms are well characterized effectors of calcium signals, and members of this family have been shown to be involved in immune receptor signaling (Shen et al., 1994; Karimi and Lennartz, 1995). We tested whether PKC was involved in fibril-stimulated signaling events by pretreatment of the THP-1 cells with a specific inhibitor to the calcium/phospholipiddependent PKCs, Go6976 (Martiny-Baron et al., 1993). PKC inhibition resulted in a decrease in protein tyrosine phosphorylation induced by both $\beta \mathrm{A} 25-35$ and $\operatorname{PrP} 106-126$ treatment of THP-1 cells (Fig. 7A). Similar results were obtained with another PKC inhibitor, chelerythrine chloride (data not shown) (Herbert, 1990). These findings established that PKC activity was required for activation of a subset of tyrosine kinases. Control studies were performed to verify that PKC activity led to tyrosine kinase activation in these cells by treatment of the cells with a phorbol ester (TPA) that induced an increase in protein tyrosine phosphorylation levels (Fig. 7B).

Pretreatment of THP-1 cells with Go6976 prevented ERK activation by $\operatorname{PrP} 106-126$ and $\beta \mathrm{A} 25-35$ (Fig. $7 C, E$ ). Control experiments verified that Go6976 pretreatment also prevented a TPA-induced activation of the ERKs in THP-1 cells (Fig. 7D). These data demonstrate that PKC can drive a tyrosine kinase- dependent pathway required for ERK activation in response to fibril stimulation.

\section{The calcium-sensitive tyrosine kinase PYK2 is activated by $\beta A$ and PrP fibril stimulation of THP-1 cells}

A recently described calcium-sensitive tyrosine kinase, PYK2, becomes activated after elevation of intracellular calcium levels (Lev et al., 1995; Li et al., 1998). The calcium-dependent regulation of PYK2 is indirect and is mediated via as yet unidentified elements. Treatment of THP-1 cells with $\beta$ A or PrP fibrils resulted in the stimulation of PYK2 tyrosine phosphorylation (Fig. $8 A$ ), which is reflective of the enzymatic activation of this enzyme (Lev et al., 1995). PYK2 phosphorylation was blocked by pretreatment of the cells with inhibitors of Lyn and PKC (PP1 and Go6976, respectively) (Fig. 8A). Moreover, inhibition of intracellular calcium release by treatment of the cells with DTBHQ also blocked fibril-mediated PYK2 activation (Fig. 8B).

As an additional means of positioning PYK2 within this pathway, we used TPA to stimulate PKC activity directly to show that PYK2 was subsequently activated (Fig. $8 C$ ). The TPA-driven PYK2 phosphorylation was inhibited by the specific PKC inhibitor Go6976. These observations demonstrate that PYK2 phosphorylation is a consequence of calcium release and PKC activation in these cells.

We performed an additional study to verify that PYK2 was being activated by the $\beta \mathrm{A}$ and $\operatorname{PrP}$ fibril stimulation pathway. The cytoskeletal protein paxillin is a known substrate of PYK2 that is phosphorylated after PYK2 activation (Hiregowdara et al., 1997; Li and Earp, 1997; Ostergaard et al., 1998). Both PrP 106-126 and $\beta A$ 25-35 stimulated an increase in paxillin phosphorylation that was inhibited by pretreating the cells with DTBHQ, PP1, and Go6976 (Fig. 8D,E). TPA stimulation of PKC activity and the subsequent PYK2 activation also led to tyrosine phosphorylation of paxillin (Fig. $8 F$ ).

These data support the conclusion that PYK2 activation in the $\beta \mathrm{A}$ and PrP pathway is a consequence of Lyn and Syk activation, intracellular calcium release, and PKC activation and is positioned downstream of these elements in the signal transduction pathway (see Fig. 11).

\section{Distinct signaling pathways lead to $\beta A$ and PrP fibril stimulation of respiratory burst and superoxide anion generation}

Macrophages respond to immune stimuli by activation of a respiratory burst leading to the generation of intracellular superoxide anion (Chanock et al., 1994; Rosen et al., 1995). Extracellular diffusion of these reactive oxygen species acts as a toxin to surrounding cells. We observed that $\beta \mathrm{A}$ and PrP fibrils induced a respiratory burst in THP-1 cells measured as the reduction of NBT by intracellular superoxide anion (Fig. 9) (Pick, 1986). The fibril-stimulated respiratory burst was not inhibited by pretreating the cells with inhibitors of Lyn, PKC, or intracellular calcium release (PP1, Go6976, or thapsigargin, respectively). These data demonstrate that NADPH oxidase activation operates via signaling pathways that are mechanistically distinct from those required for ERK activation and stimulation of cytokine synthesis (Tannenbaum and Hamilton, 1989; Wood, 1994; SchmidAlliana et al., 1998). 
A

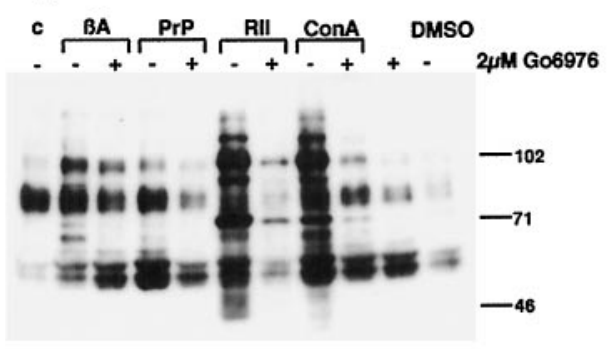

B

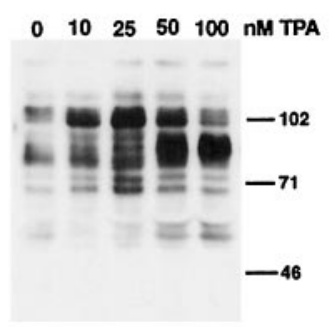

c

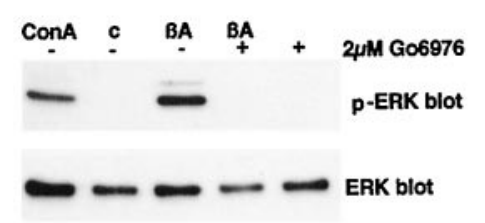

。 incubation in $\operatorname{PrP} 106-126$ ( $80 \mu \mathrm{M} ; 5 \mathrm{~min})$ or $\beta A 25-35(40$ $\mu \mathrm{M} ; 2 \mathrm{~min}$ ) or cross-linking of $\mathrm{Fc}_{\gamma} \mathrm{R}_{\mathrm{II}}\left[25 \mu \mathrm{g} / \mathrm{ml}\right.$ anti-Fc $\mathrm{R}_{\mathrm{II}}$ $\mathrm{Ab}+100 \mu \mathrm{g} / \mathrm{ml} \mathrm{G} \alpha \mathrm{M} \mathrm{Fab}_{2}$ (15 min on ice with $\mathrm{Ab}+2 \mathrm{~min}$ at $37^{\circ} \mathrm{C}$ with $\left.\mathrm{Fab}_{2}\right)$ ] or Con A $(60 \mu \mathrm{g} / \mathrm{ml} ; 5 \mathrm{~min})$ as a positive control. Aliquots of cell lysate were resolved by SDS-PAGE, Western blotted, and visualized by chemiluminescence. $A$, Protein phosphotyrosine levels were compared, using the anti-phosphotyrosine antibody 4G10, when THP-1 cells were preincubated in $2 \mu \mathrm{M}$ Go6976 before stimulation with $\operatorname{Pr} P 106-126$ and $\beta A$ 25-35. B, Changes in protein tyrosine phosphorylation were also monitored when THP-1 cells were incubated in ethanol vehicle (0 nM TPA) or in increasing concentrations of the phorbol ester TPA. Cell lysates were also Western blotted using an antibody directed against the activated, phosphorylated forms of ERK1 and ERK2. Blots were stripped and reprobed with an anti-ERK antibody to normalize for protein load. $C-E$, ERK phosphorylation and activation were examined in THP-1 cells pretreated with $2 \mu \mathrm{M}$ Go6976 before stimulation with $\beta A$ 25-35 (C), $\operatorname{PrP} 106-126(E)$, or $100 \mathrm{~nm} \mathrm{TPA}$ $(D)$.

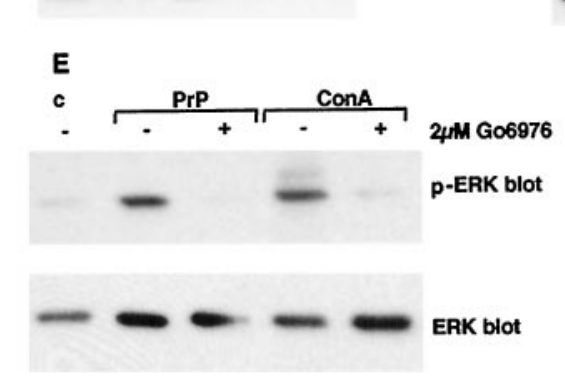

The $\beta A$ and PrP fibril-stimulated tyrosine kinase signaling pathway stimulates THP-1 monocytes to produce neurotoxic factor(s)

Numerous reports have described the ability of microglial lineage cells to generate neurotoxic products in response to treatments with $\beta$ A or PrP peptides (Forloni et al., 1993; Giulian et al., 1995; Brown et al., 1996; Ii et al., 1996; Klegeris and McGeer, 1997; Klegeris et al., 1997; Kretzschmar et al., 1997; Lorton, 1997; McDonald et al., 1997; C. K. Combs, D. R. McDonald, and G. E. Landreth, unpublished observations). We used a tissue culture system that uses highly purified populations of primary mouse neurons either cocultured with purified mouse microglia or cultured in conditioned media from THP-1 cells to establish whether the elaboration of neurotoxic and proinflammatory products was dependent on the tyrosine kinase-based signaling pathways identified here. Purified mouse microglia and THP-1 cells were stimulated with PrP 106-126, $\beta$ A 25-35, or $\beta$ A 1-40 for $48 \mathrm{hr}$ with or without the presence of selected, specific enzyme inhibitors. We observed that conditioned media from untreated THP-1 cells or microglia provoked only a low level of neuronal death (Fig. 10). However, incubation of neurons with conditioned medium from $\beta \mathrm{A}$ - and PrP-stimulated THP-1 cells or microglia resulted in a dramatically greater degree of neuronal death.

To evaluate whether the tyrosine kinase-based signaling pathways were responsible for generating the neurotoxic products, inhibitors of specific enzymes in the pathway were used to treat the THP-1 cells during the $48 \mathrm{hr}$ period of $\beta \mathrm{A}$ and $\operatorname{PrP}$ fibril stimulation. Treatment of THP-1 cells with PP1, Go6976, and piceatannol (inhibiting Lyn, PKC, and Syk, respectively) inhibited the production of neurotoxic products (Fig. 10C,D). We also pretreated THP-1 cells with the MEK inhibitor PD98095 to inhibit ERK activation downstream of $\beta \mathrm{A}$ and PrP fibril stimu- lation (Alessi et al., 1995). A similar neuroprotective effect was observed. These data clearly demonstrate that the fibril-activated signaling pathways we have defined are directly responsible for the generation of neurotoxic products (Fig. 11).

\section{DISCUSSION}

There is compelling evidence that inflammatory processes play a significant role in the pathophysiology of AD (McGeer et al., 1993; McGeer and McGeer, 1995). Indeed, in a number of studies, treatment with nonsteroidal anti-inflammatory drugs (NSAIDS) has been shown to reduce dramatically the incidence of AD-related dementia (Rich et al., 1995; McGeer and McGeer, 1996; McGeer et al., 1996). Recently, Stewart et al. (1997) have documented in a longitudinal study that patient populations treated over extended intervals with these drugs were found to be at a substantially reduced risk of acquiring AD. The principal action of these drugs is to suppress the production of proinflammatory products that are primarily secretory products of microglia. NSAID use was correlated with a significant reduction in the number of activated microglia present in the AD brain (Mackenzie and Munoz, 1998). The association of reactive microglia with amyloid deposits in the brain is an invariant feature of AD, its animal models, and a subset of the prion diseases. Several studies have demonstrated an ability of both $\beta \mathrm{A}$ and $\mathrm{PrP}$ peptide fibrils to activate microglia to secrete cytokines, reactive oxygen species, and other neurotoxins (Forloni et al., 1993; Giulian et al., 1995; Brown et al., 1996; Ii et al., 1996; Klegeris and McGeer, 1997; Klegeris et al., 1997; Kretzschmar et al., 1997; Lorton, 1997; McDonald et al., 1997; Combs, McDonald, and Landreth, unpublished observations).

We have demonstrated that microglia can respond to fibrillar amyloid peptides by initiation of a complex signal transduction 

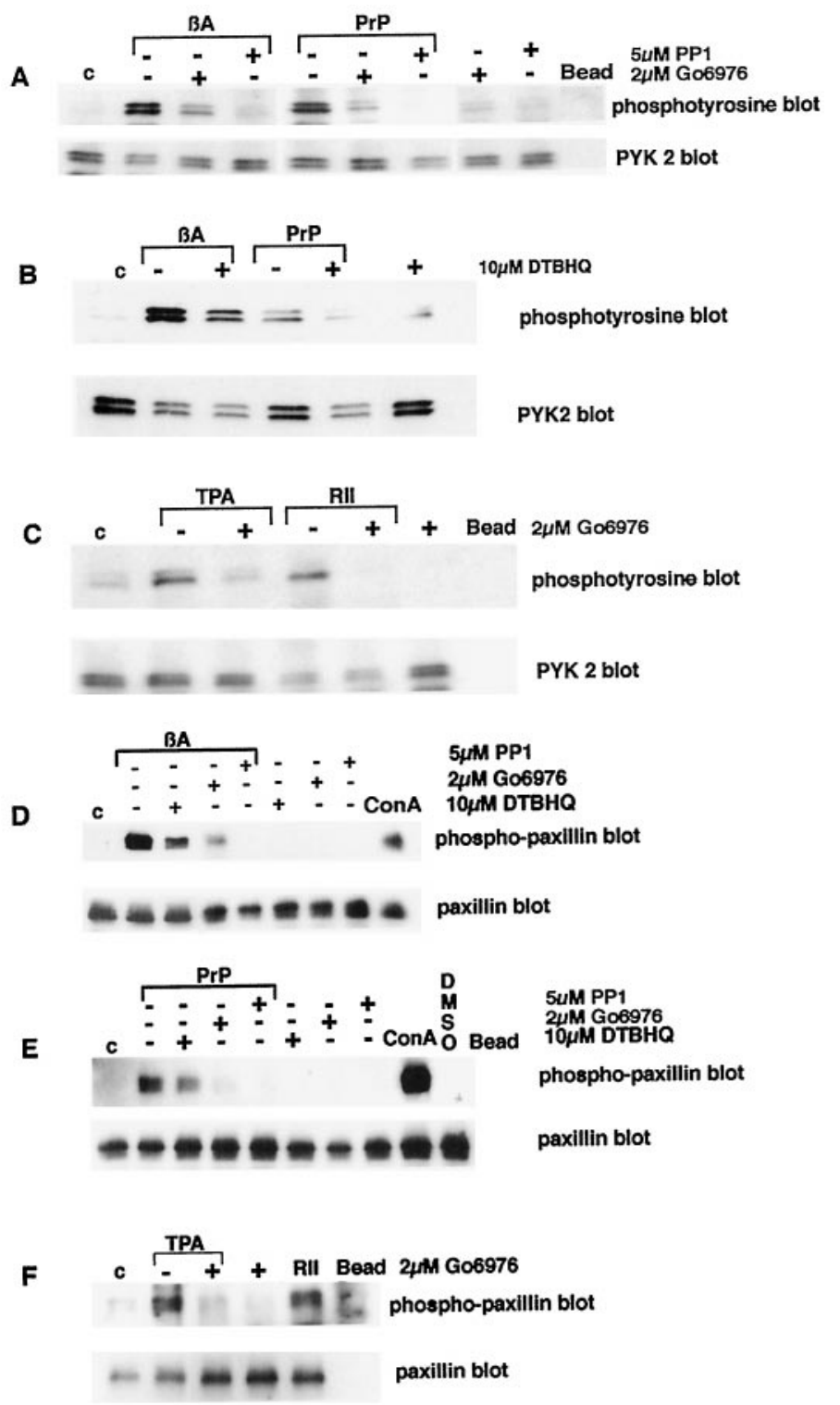

Figure 8. The calcium-sensitive tyrosine kinase $P Y K 2$ is activated after $\beta A$ and $\operatorname{Pr} P$ fibril stimulation of THP- 1 cells. THP- 1 cells were incubated in $D M S O$ vehicle $(c), 50 \mathrm{~nm}$ thapsigargin, $10 \mu \mathrm{M} D T B H Q, 5 \mu \mathrm{M} P P 1$, or 2 $\mu \mathrm{M}$ Go6976 (45 $\mathrm{min} ; 37^{\circ} \mathrm{C}$ for each) before incubation in $\operatorname{PrP} 106-126$ (80 $\mu \mathrm{M} ; 5 \mathrm{~min})$ or $\beta A 25-35(40 \mu \mathrm{M} ; 2 \mathrm{~min})$ or cross-linking of $\mathrm{Fc}_{\gamma} \mathrm{R}_{\mathrm{II}}[25$ $\mu \mathrm{g} / \mathrm{ml}$ anti-Fc $\mathrm{C}_{\gamma} \mathrm{R}_{\mathrm{II}} \mathrm{Ab}+100 \mu \mathrm{g} / \mathrm{ml} \mathrm{G} \alpha \mathrm{M} \mathrm{Fab}_{2}$ (15 min on ice with $\mathrm{Ab}+$ $2 \mathrm{~min}$ at $37^{\circ} \mathrm{C}$ with $\left.\mathrm{Fab}_{2}\right)$ ] or Con A $(60 \mu \mathrm{g} / \mathrm{ml} ; 5 \mathrm{~min})$ as a positive control. The tyrosine kinase PYK2 and the cytoskeletal protein paxillin were immunoprecipitated from lysates of THP-1 cells and resolved by SDS-PAGE. The anti-phosphotyrosine antibody 4G10 was used to Western blot the immunoprecipitated proteins. The blots were stripped and reprobed with the immunoprecipitating antibodies to normalize for protein load. $A, B, D, E$, Changes in $P Y K 2(A, B)$ and paxillin $(D, E)$ tyrosine phosphorylation were observed after pretreatment of THP-1 cells with 10 $\mu \mathrm{M} D T B H Q, 5 \mu \mathrm{M} \mathrm{PP1}$, or $2 \mu \mathrm{M}$ Go6976 before stimulation with $\operatorname{Pr} P$ $106-126$ and $\beta A$ 25-35. $C, F$, Changes in PYK2 $(C)$ and paxillin $(F)$ tyrosine phosphorylation were also observed after pretreatment of THP-1 cells with $2 \mu \mathrm{M}$ Go6976 before stimulation with $100 \mathrm{~nm}$ TPA.

cascade leading to the acquisition of a reactive phenotype and the synthesis of acute phase and proinflammatory products (McDonald et al., 1997). The microglia respond to either $\beta \mathrm{A}$ or PrP fibrils by activating a common tyrosine kinase-dependent signaling response (McDonald et al., 1997, 1998; Combs, McDonald,

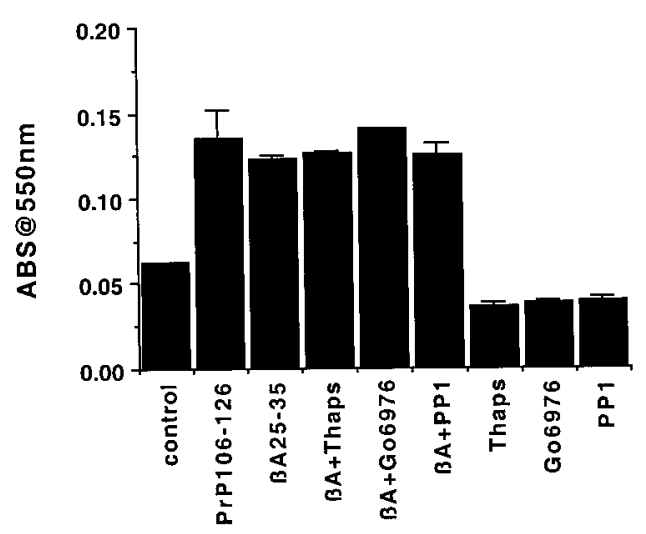

Figure 9. $\quad \beta A$ and $\operatorname{Pr} P$ fibrils stimulate a respiratory burst in THP-1 cells. THP-1 cells were incubated in DMSO vehicle (control), 50 nM thapsigargin (Thaps), $5 \mu \mathrm{M} \mathrm{PP1}$, or $2 \mu \mathrm{M}$ Go6976 (30 min; $37^{\circ} \mathrm{C}$ for each) before incubation in $\operatorname{Pr} P$ 106-126 $(40 \mu \mathrm{M})$ or $\beta A 25-35(40 \mu \mathrm{M})$. Cells were stimulated for $30 \mathrm{~min}$ in HBSS containing $1 \mu \mathrm{g} / \mathrm{ml} \mathrm{NBT}$. Cells were collected and sonicated in RIPA buffer. Generation of superoxide anion was measured by the change in absorbance at $550 \mathrm{~nm}$. The mean absorbance values $( \pm$ SEM) representative of three independent experiments are shown.

and Landreth, unpublished observations). The signaling pathways activated by amyloid fibrils are also used by classical immune receptors in cells of this lineage to elicit a proinflammatory response and acquisition of a reactive phenotype. This provides a mechanistic explanation for the functionally similar response to the two classes of stimuli.

The present study extends our previous work by identifying new elements that participate in the amyloid-induced signaling cascades and by establishing the position of the various signaling elements within the pathways. We have demonstrated previously that the tyrosine kinases Lyn and Syk are both activated as proximal components in this fibril-stimulated signaling cascade (McDonald et al., 1997, 1998; Combs, McDonald, and Landreth, unpublished observations). This is analogous to typical inflammatory signaling pathways such as those mediated via immune receptors like $\mathrm{Fc}_{\gamma} \mathrm{R}_{\mathrm{II}}$. The present study has demonstrated that amyloid stimulation leads to the elevation of intracellular calcium levels as a consequence of its release from intracellular stores. Significantly, the fibril-induced calcium mobilization does not involve the action of $\mathrm{PLC}_{\gamma 1}$ that mechanistically distinguishes this signaling event from that used by $\mathrm{Fc}_{\gamma} \mathrm{R}_{\mathrm{II}} \cdot \mathrm{Fc}_{\gamma} \mathrm{R}_{\mathrm{II}}$ uses Syk to phosphorylate and activate $\mathrm{PLC}_{\gamma 1}$ for phosphotidylinositol 4,5bisphosphate cleavage, generation of $\mathrm{IP}_{3}$, intracellular calcium release, and subsequent PKC activation (Liao et al., 1992; Rankin et al., 1993; Shen et al., 1994). Amyloid fibril exposure leads to the activation of calcium/phospholipid-dependent PKC isoforms. These events are necessary not only for the subsequent activation of the calcium-sensitive tyrosine kinase PYK2 but also for the downstream activation of the ERKs. It is unclear whether PYK2 activation is required for ERK activation in the $\beta A$ and PrP fibril signaling pathway. In other cell types, however, PYK2 activation is clearly linked to ras/raf-dependent ERK activation via binding to the small adapter protein shc (Lev et al., 1995; Della Rocca et al., 1997).

In the AD brain, plaque-associated microglia exhibit elevated levels of tyrosine phosphoproteins, indicative of sustained activation of intracellular signaling pathways (Wood and Zinsmeister, 1991). We have now established, using an in vitro model, that the sustained contact of monocytes and microglia with fibrillar pep- 


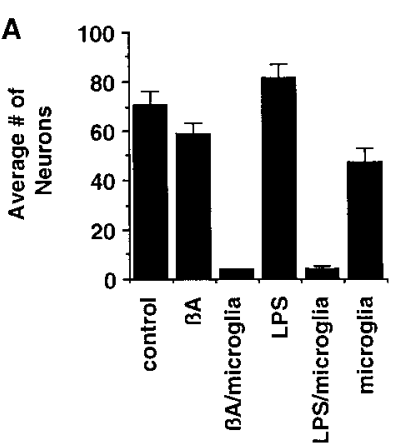

C
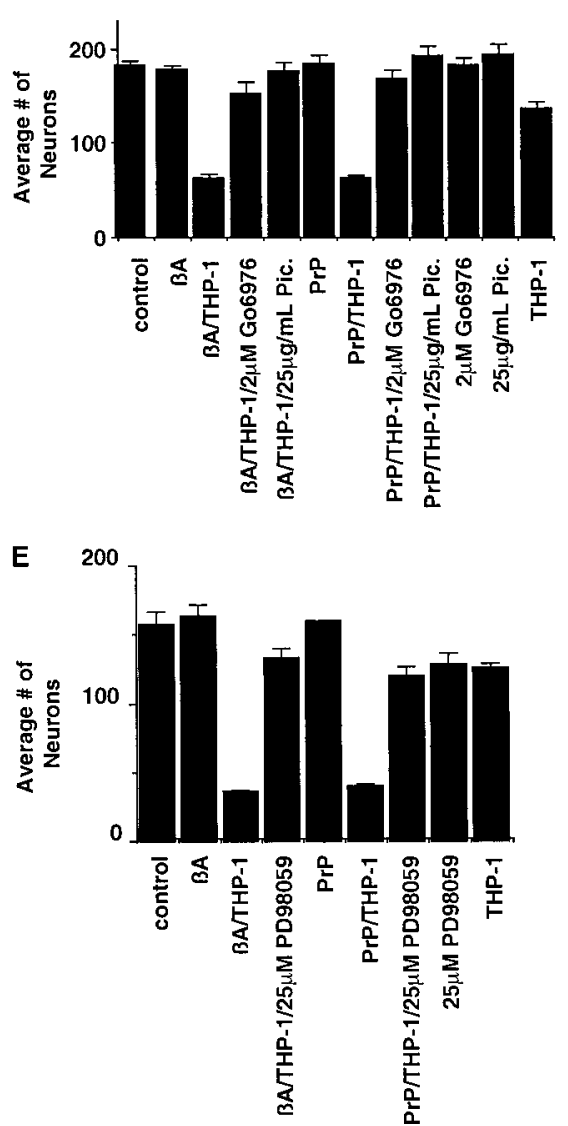

B

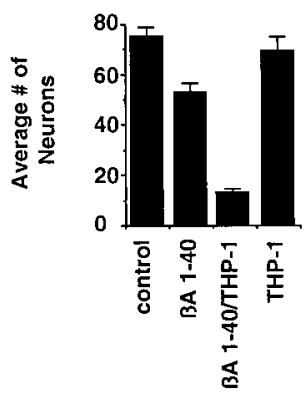

D

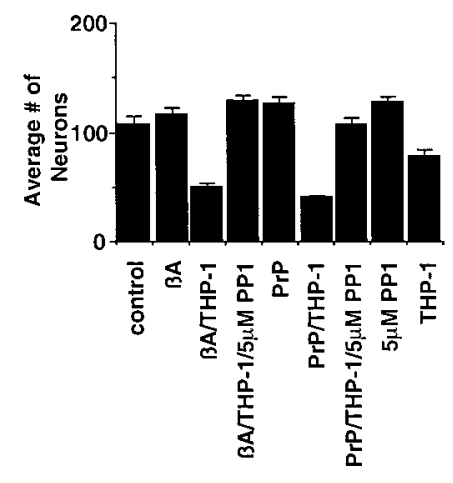

Figure 10. $\beta A$ and $\operatorname{Pr} P$ fibrils stimulate microglia and THP-1 monocytes to secrete neurotoxic products. Purified cultures of mouse cortical neurons (E17; 5-7 d in vitro) were cultured alone or in the presence of microglia or conditioned media from $T H P-1$ cells $\left(4.0 \times 10^{4}\right.$ neurons $/ 1.8 \times$ $10^{4}$ microglia or THP-1 cells). $A$, Microglia were added to neuronal cultures, along with the peptide fibrils $\beta A 25-35$ $(1 \mu \mathrm{M})$ or $1 \mu \mathrm{g} / \mathrm{ml}$ LPS as a positive control for $48 \mathrm{hr}$. $B-E$, $T H P-1$ cells were also stimulated for $48 \mathrm{hr}$ by plating into tissue culture wells coated with the peptides $\operatorname{PrP} 106-$ $126, \beta A 1-40$, and $\beta A 25-35$ (48 pmole $\left./ \mathrm{mm}^{2}\right)$ in the presence of DMSO vehicle (control) or $25 \mu \mathrm{g} / \mathrm{ml}$ piceatannol (Pic.; C), $2 \mu \mathrm{M}$ Go6976 (C), $5 \mu \mathrm{M} \mathrm{PP1} \mathrm{(D),} \mathrm{and} 25 \mu \mathrm{M}$ $P D 98095(E)$. Conditioned medium was obtained from wells in which THP-1 cells were incubated in the absence or presence of $\beta A$ or $\operatorname{Pr} P$ as well as control incubations of the medium alone or medium from wells containing only surface-bound $\beta A$ or $\operatorname{Pr} P$. Evaluation of the effects of the various drugs included parallel incubations in the absence or presence of $T H P-1$ cells. Conditioned medium was added to mouse cortical neuron cultures for $72 \mathrm{hr}$. Microglianeuron cocultures were maintained for $48 \mathrm{hr}$. Neurons were then fixed, stained for neuron-specific MAP2 protein, and counted. Neurons from four fields per condition were counted in duplicate wells and averaged ( \pm SEM). Graphs are a representative of four independent experiments.

tides results in constitutively elevated phosphotyrosine levels. This closely resembles the in vivo condition of plaque-associated microglia in AD brains. This cascade is specific for the fibrillar forms of the peptides and does not seem to involve peptide binding to scavenger or RAGE receptors (McDonald et al., 1997; Combs, McDonald, and Landreth, unpublished observations).

Numerous in vitro studies have demonstrated that $\beta \mathrm{A}$ and PrP fibril stimulation of microglia leads to the acquisition of a neurotoxic phenotype (Forloni et al., 1993; Giulian et al., 1995; Brown et al., 1996; Ii et al., 1996; Klegeris and McGeer, 1997; Klegeris et al., 1997; Kretzschmar et al., 1997; Lorton, 1997; McDonald et al., 1997; Combs, McDonald, and Landreth, unpublished observations). Although the amyloid-induced production of neurotoxins is well documented, the identity of the species responsible for neuronal death remains controversial (Forloni et al., 1993; Giu- lian et al., 1995; Brown et al., 1996; Ii et al., 1996; Klegeris and McGeer, 1997; Klegeris et al., 1997; Kretzschmar et al., 1997; Lorton, 1997; McDonald et al., 1997; Combs, McDonald, and Landreth, unpublished observations) but reflects the activation of a coordinated response pathway and the synthesis of numerous proinflammatory species. We have used a well established in vitro model to investigate whether the amyloid-stimulated signaling pathways we have characterized are linked to the production of neurotoxic products (Giulian et al., 1995). We report that treatment of microglia or THP-1 cells with inhibitors that target specific protein kinases that comprise the $\beta \mathrm{A}$ - and PrP-activated signaling pathway (e.g., Lyn, Syk, PKC, and ERK) effectively blocked the amyloid-stimulated production of neurotoxins and promoted neuron survival. These experiments verified that the tyrosine kinase-based inflammatory pathways were directly re- 


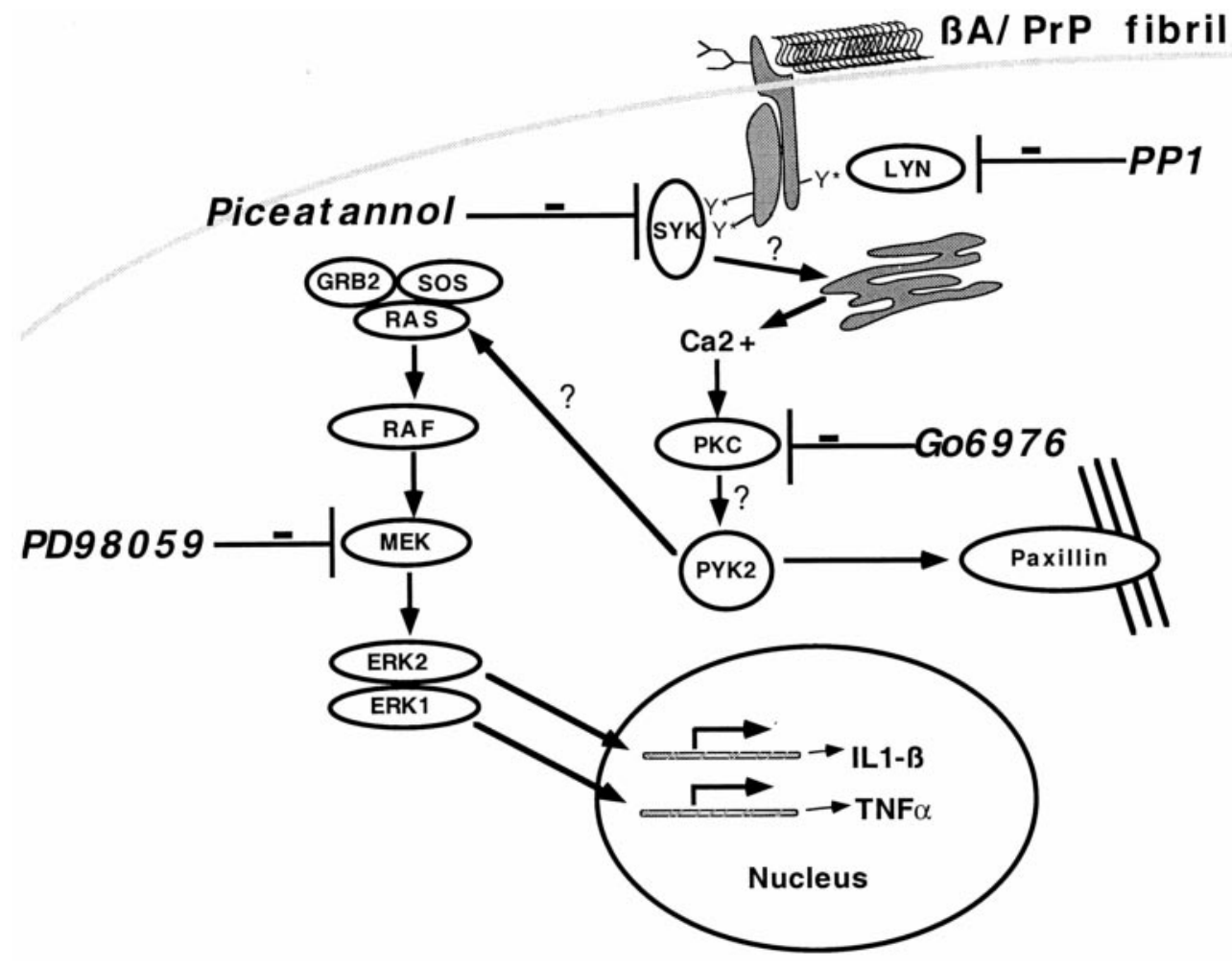

Figure 11. Mechanism of microglial activation by fibrillar $\beta A$ and $\operatorname{Pr} P$ peptides responsible for neurotoxicity. A schematic is shown detailing the defined tyrosine kinase-based signaling pathway by which $\beta A$ and $\operatorname{Pr} P$ fibrils activate microglia and monocytes to elicit production of neurotoxic factors. Indicated are points in the signaling pathway at which specific enzyme inhibition can alleviate production of the neurotoxic products. IL1- $\beta$, Interleukin-1- $\beta ; T N F \alpha$, tumor necrosis factor $\alpha ; Y$, tyrosine phosphorylation.

sponsible for production of neurotoxic factors and have validated the approach of using agents that specifically target elements of the signal transduction apparatus.

We have shown that microglia and other cells of this lineage respond to exposure to amyloid fibrils by initiation of complex signal transduction cascades. These signaling pathways are also activated in response to immune stimuli and effect a sophisticated and coordinated cellular response leading to the production of a diverse range of bioactive molecules and cellular behaviors. The efficacy of nonsteroidal anti-inflammatory drugs in reducing the incidence and progression of AD provides strong support for the critical involvement of inflammatory processes in the etiology of $\mathrm{AD}$ and related diseases. The molecular dissection of these pathways has allowed us to identify constituents of these cascades and to test directly whether the selective inhibition of these enzymes inhibits the production of proinflammatory products and ameliorates the neurotoxicity associated with amyloid exposure. The data have shown clearly that this strategy is effective in our in vitro model system. The detailed knowledge of the microglial intracellular signaling pathways may allow novel therapeutic approaches to $\mathrm{AD}$ and related diseases.

\section{REFERENCES}

Alessi DR, Cuenda A, Cohen P, Dudley DT, Saltiel AR (1995) PD 098059 is a specific inhibitor of the activation of mitogen-activated protein kinase kinase in vitro and in vivo. J Biol Chem 270:27489-27494.

Betmouni S, Perry VH, Gordon JL (1996) Evidence for an early inflammatory response in the central nervous system of mice with scrapie. Neuroscience 74:1-5.

Bissonnette M, Tien XY, Niedziela SM, Hartmann SC, Frawley BPJ, Roy HK, Sitrin MD, Perlman RL, Brasitus TA (1994) 1,25(OH)2 vitamin D3 activates PKC-alpha in Caco-2 cells: a mechanism to limit secosteroid-induced rise in $\left[\mathrm{Ca}^{2+}\right]_{\mathrm{i}}$. Am J Physiol 267:G465-G475.

Borchelt DR, Taraboulos A, Prusiner SB (1992) Evidence for synthesis of scrapie prion proteins in the endocytic pathway. J Biol Chem 267:16188-16199.

Braak H, Braak E (1997) Frequency of stages of Alzheimer-related lesions in different age categories. Neurobiol Aging 18:351-357.

Bradford MM (1976) A rapid and sensitive method for the quantitation of microgram quantities of protein utilizing the principle of protein-dye binding. Anal Biochem 72:248-254.

Brewer GJ, Torricelli JR, Evege EK, Price PJ (1993) Optimized survival of hippocampal neurons in B-27 supplemented neurobasal media. J Neurosci Res 35:567-576.

Brown DR, Kretzschmar HA (1997) Microglia and prion disease: a review. Histol Histopathol 12:883-892.

Brown DR, Schmidt B, Kretzschmar HA (1996) Role of microglia and host prion protein in neurotoxicity of a prion protein fragment. Nature 380:345-347.

Carafoli E (1987) Intracellular calcium homeostasis. Annu Rev Biochem 56:395-433.

Chanock SJ, el Benna J, Smith RM, Babior BM (1994) The respiratory burst oxidase. J Biol Chem 269:24519-24522.

Charles AC, Dirksen ER, Merrill JE, Sanderson MJ (1993) Mechanisms of intercellular calcium signaling in glial cells studied with dantrolene and thapsigargin. Glia 7:134-145.

Chen SG, Teplow DB, Parchi P, Teller JK, Gambetti P, Autilio-Gambetti L (1995) Truncated forms of the human prion protein in normal brain and in prion diseases. J Biol Chem 270:19173-19180.

Cotman CW, Tenner AJ, Cummings BJ (1996) $\beta$-Amyloid converts an acute phase injury response to chronic injury responses. Neurobiol Aging 17:723-731.

Crowley MT, Costello PS, Fitzer-Attas CJ, Turner M, Meng F, Lowell C, Tybulewicz VLJ, DeFranco AL (1997) A critical role for Syk in signal transduction and phagocytosis mediated by $\mathrm{Fc} \gamma$ receptors on macrophages. J Exp Med 186:1027-1039.

Della Rocca GJ, van Biesen T, Daaka Y, Luttrell DK, Luttrell LM, Lefkowitz RJ (1997) Ras-dependent mitogen-activated protein kinase activation by $\mathrm{G}$ protein-coupled receptors. Convergence of Gi- and Gq-mediated pathways on calcium/calmodulin, Pyk2, and Src kinase. J Biol Chem 272:19125-19132.

Di Virgilio F, Fasolato C, Steinberg T (1988) Inhibitors of membrane transport for organic anions block fura-2 excretion from PC12 and N2A cells. Biochem J 256:959-963. 
El-Moatassim C, Dubyak GR (1992) A novel pathway for the activation of phospholipase $\mathrm{D}$ by $\mathrm{P} 2 \mathrm{z}$ purinergic receptors in BAC1.2F5 macrophages. J Biol Chem 267:23664-23673.

Florio T, Grimaldi M, Scorziello A, Salmona M, Bugiani O, Tagliavini F, Forloni G, Schettini G (1996) Intracellular calcium rise through L-type calcium channels, as molecular mechanism for prion protein fragment 106-126-induced astroglial proliferation. Biochem Biophys Res Commun 228:397-405.

Forloni G, Angeretti N, Chiesa R, Monzani E, Salmona M, Bugiani O, Tagliavani F (1993) Neurotoxicity of a prion protein fragment. Nature 362:543-546.

Fraser SP, Suh Y-H, Djamgoz MBA (1997) Ionic effects of the Alzheimer's disease $\beta$-amyloid precursor protein and its metabolic fragments. Trends Neurosci 20:67-72.

Gasset M, Baldwin MA, Lloyd DH, Gabriel J-M, Holtzman DM, Cohen F, Fletterick R, Prusiner SB (1992) Predicted alpha-helical regions of the prion protein when synthesized as peptides form amyloid. Proc Natl Acad Sci USA 89:10940-10944.

Ghazizadeh S, Bolen JB, Fleit HB (1994) Physical and functional association of Src-related protein tyrosine kinases with Fc gamma RII in monocytic THP-1 cells. J Biol Chem 269:8878-8884.

Ghazizadeh S, Bolen JB, Fleit HB (1995) Tyrosine phosphorylation and association of Syk with Fc $\gamma$ RII in monocytic THP-1 cells. Biochem $\mathrm{J}$ 305:669-674.

Giulian D, Haverkamp LJ, Li J, Karshin WL, Yu J, Tom D, Li X, Kirkpatrick JB (1995) Senile plaques stimulate microglia to release a neurotoxin found in Alzheimer brain. Neurochem Int 27:119-137.

Guiroy DC, Wakayama I, Liberski PP, Gadjusek DC (1994) Relationship of microglia and scrapie amyloid-immunoreactive plaques in kuru, Creutzfeldt-Jakob disease and Gerstmann-Straussler syndrome. Acta Neuropathol (Berl) 87:526-530.

Haas C, Schlossmacher MG, Hung AY, Vigo-Pelfrey C, Mellon A, Ostaszewski BL, Lieberberg I, Koo EH, Schenk D, Teplow DB, Selkoe DJ (1992) Amyloid $\beta$-peptide is produced by cultured cells during normal metabolism. Nature 359:322-325.

Hanke JH, Gardner JP, Dow RL, Changelian PS, Brissette WH, Weringer EJ, Pollock BA, Connelly PA (1996) Discovery of a novel, potent, and src family-selective tyrosine kinase inhibitor. J Biol Chem 271:695-701.

Herbert JM (1990) Chelerythrine is a potent and specific inhibitor of protein kinase C. Biochem Biophys Res Commun 172:993-999.

Herms JW, Madlung A, Brown DR, Kretzschmar HA (1997) Increase of intracellular free $\mathrm{Ca} 2+$ in microglia activated by prion protein fragment. Glia 21:253-257.

Hiregowdara D, Avraham H, Fu Y, London R, Avraham S (1997) Tyrosine phosphorylation of the related adhesion focal tyrosine kinase in megakaryocytes upon stem cell factor and phorbol myristate acetate stimulation and its association with paxillin. $\mathrm{J}$ Biol Chem 272:10804-10810.

Ii M, Sunamoto M, Ohnishi K, Ichimori Y (1996) $\beta$-Amyloid proteindependent nitric oxide production from microglial cells and neurotoxicity. Brain Res 720:93-100.

Itagaki S, McGeer PL, Akiyama H, Zhu S, Selkoe D (1989) Relationship of microglia and astrocytes to amyloid deposits of Alzheimer disease. J Neuroimmunol 24:173-182.

Jeffrey M, Goodsir CM, Bruce ME, McBride PA, Farquhar C (1994) Morphogenesis of amyloid plaques in $87 \mathrm{~V}$ murine scrapie. Neuropathol Appl Neurobiol 20:535-542.

Kang J, Lemaire H, Unterbeck A, Slabaum J, Masters C, Grzeschik K, Multhaup G, Beyreuther K, Muller-Hill B (1987) The precursor of Alzheimer's disease amyloid $\beta 4$ protein resembles a cell surface receptor. Nature 325:733-735.

Karimi K, Lennartz MR (1995) Protein kinase C activation precedes arachidonic acid release during IgG-mediated phagocytosis. J Immunol 155:5786-5794.

Khan YM, Wictome M, East JM, Lee AG (1995) Interactions of dihydroxybenzenes with the $\mathrm{Ca}(2+)$ ATPase: separate binding sites for dihydroxybenzenes and sesquiterpene lactones. Biochemistry 34:14385-14393.

Kisilevsky R (1997) Can deposition of amyloid be prevented in Alzheimer's disease. Ann NY Acad Sci 826:117-127.

Klegeris A, McGeer P (1997) $\beta$-Amyloid protein enhances macrophage production of oxygen free radicals and glutamate. J Neurosci Res 49:229-235.

Klegeris A, Walker DG, McGeer PL (1997) Interaction of Alzheimer beta-amyloid peptide with the human monocytic cell line THP-1 results in a protein kinase C-dependent secretion of tumor necrosis factoralpha. Brain Res 747:114-121.

Koo EH, Squazzo SL (1994) Evidence that production and release of amyloid $\beta$-protein involves the endocytic pathway. J Biol Chem 269:17386-17389.

Korotzer AR, Whittemore ER, Cotman CW (1995) Differential regulation by $\beta$-amyloid peptides of intracellular free $\mathrm{Ca} 2+$ concentration in cultured rat microglia. Eur J Pharmacol 288:125-130.

Kretzschmar HA, Prusiner SB, Stowring LE, DeArmond SJ (1986) Scrapie prion proteins are synthesized in neurons. Am J Pathol 122:1-5.

Kretzschmar HA, Giese A, Brown DR, Herms J, Keller B, Schmidt B, Groschup M (1997) Cell death in prion disease. J Neural Transm 50:191-210.

Lagenaur C, Lemmon V (1987) An L1-like molecule, the 8D9 antigen, is a potent substrate for neurite extension. Proc Natl Acad Sci USA 84:7753-7757.

Lev S, Moreno H, Martinez R, Canoll P, Peies E, Musacchio JM, Plowman GD, Rudy B, Shlessinger J (1995) Protein tyrosine kinase PYK2 involved in $\mathrm{Ca}^{2+}$-induced regulation of ion channel and MAP kinase functions. Nature 376:737-745.

Li X, Earp HS (1997) Paxillin is tyrosine phosphorylated by and preferentially associates with the calcium-dependent tyrosine kinase in rat liver epithelial cells. J Biol Chem 272:14341-14348.

Li X, Hunter D, Morris J, Haskill JS, Earp HS (1998) A calciumdependent tyrosine kinase splice variant in human monocytes. J Biol Chem 273:9361-9364.

Liao F, Shin HS, Rhee SG (1992) Tyrosine phosphorylation of phospholipase C- $\gamma 1$ induced by cross-linking of the high-affinity or low affinity Fc receptor for IgG in U937 cells. Proc Natl Acad Sci 89:3659-3663.

Lin M-C, Mirzabekov T, Kagan BL (1997) Channel formation by a neurotoxic prion protein fragment. J Biol Chem 272:44-47.

Lorton D (1997) Beta-amyloid-induced IL-1 beta release from an activated human monocyte cell line is calcium- and G-protein-dependent. Mech Aging Dev 94:199-211.

Mackenzie IR, Munoz DG (1998) Nonsteroidal anti-inflammatory drug use and Alzheimer-type pathology in aging. Neurology 50:986-990.

Marcilla A, Rivero-Lezcano OM, Agarwal A, Robbins KC (1995) Identification of the major tyrosine kinase substrate in signaling complexes formed after engagement of Fc $\gamma$ receptors. J Biol Chem 270:9115-9120.

Martiny-Baron G, Kazanietz MG, Mischak H, Blumberg PM, Kochs G, Hug H, Marme D, Schachtele C (1993) Selective inhibition of protein kinase C isozymes by the indolocarbazole Go 6976. J Biol Chem 268:9194-9197.

McDonald D, Bamberger M, Combs C, Landreth G (1998) $\beta$-Amyloid fibrils activate parallel mitogen-activated protein kinase pathways in microglia and THP-1 monocytes. J Neurosci 18:4451-4460.

McDonald DR, Brunden KR, Landreth GE (1997) Amyloid fibrils activate tyrosine kinase-dependent signaling and superoxide production in microglia. J Neurosci 17:2284-2294.

McGeer PL, McGeer EG (1995) The inflammatory response system of brain: implications for therapy of Alzheimer and other neurodegenerative diseases. Brain Res Rev 21:195-218.

McGeer PL, McGeer EG (1996) Anti-inflammatory drugs in the fight against Alzheimer's disease. Ann NY Acad Sci 777:213-220.

McGeer PL, Rogers J (1992) Anti-inflammatory agents as a therapeutic approach to Alzheimer's disease. Neurology 42:447-449.

McGeer PL, Kawamata T, Walker DG, Akiyama H, Tooyama I, McGeer EG (1993) Microglia in degenerative neurological disease. Glia 7:84-92

McGeer PL, Schulzer M, McGeer EG (1996) Arthritis and antiinflammatory agents as possible protective factors for Alzheimer's disease: a review of 17 epidemiologic studies. Neurology 47:425-432.

Miyazono M, Iwaki T, Kitamoto T, Kaneko Y, Doh-ura K, Tateishi J (1991) A comparative immunohistochemical study of kuru and senile plaques with a special reference to glial reactions at various stages of amyloid plaque formation. Am J Pathol 139:589-598.

Muhleisen H, Gehrmann J, Meyermann R (1995) Reactive microglia in Creutzfeldt-Jakob disease. Neuropathol Appl Neurobiol 21:505-517.

Odin JA, Edberg JC, Painter CJ, Kimberly RP, Unkeless JC (1991) Regulation of phagocytosis and $\left[\mathrm{Ca}^{2+}\right]_{\mathrm{i}}$ flux by distinct regions of the Fc receptor. Science 254:1785-1788.

Oesch B, Westaway D, Wälchli M, McKinley MP, Kent SBH, Abersold R, Barry RA, Tempst P, Teplow DB, Hood LE, Prusiner SB, Weissmann 
C (1985) A cellular gene encodes scrapie PrP 27-30 protein. Cell 40:735-746.

Oliver JM, Burg DL, Wilson BS, McLaughlin JL, Geahlen RL (1994) Inhibition of mast cell Fc $\in \mathrm{R} 1$-mediated signaling and effector function by the syk-selective inhibitor, piceatannol. J Biol Chem 269: 29697-29703.

Ostergaard HL, Lou O, Arendt CW, Berg NN (1998) Paxillin phosphorylation and association with Lck and Pyk2 in anti-CD3- or antiCD45-stimulated T cells. J Biol Chem 273:5692-5696.

Palade P, Dettbarn C, Alderson B, Volpe P (1989) Pharmacological differentiation between inositol-1,4,5-triphosphate-induced $\mathrm{Ca} 2+$ release and $\mathrm{Ca} 2+$-or caffeine-induced $\mathrm{Ca} 2+$ release from intracellular membrane systems. Mol Pharmacol 36:673-680.

Pick E (1986) Microassay for superoxide and hydrogen peroxide production and nitroblue tetrazolium reduction using an enzyme immunosassay microplate reader. Methods Enzymol 132:407-421.

Prusiner SB (1982) Novel proteinaceous infectious particles cause scrapie. Science 216:136-144.

Prusiner SB, Groth DF, Bolton DC, Kent SB, Hood LE (1984) Purification and structural studies of a major scrapie prion protein. Cell 38:127-134.

Rankin BM, Yocum SA, Mittler RS, Kiener PA (1993) Stimulation of tyrosine phosphorylation and calcium mobilization by $\mathrm{Fc} \gamma$ receptor cross-linking. J Immunol 150:605-616.

Rich JB, Rasmusson DX, Folstein MF, Carson KA, Kawas C, Brandt J (1995) Nonsteroidal anti-inflammatory drugs in Alzheimer's disease. Neurology 45:51-55.

Rosen GM, Pou S, Ramos CL, Cohen MS, Britigan BE (1995) Free radicals and phagocytic cells. FASEB J 9:200-209.

Schmid-Alliana A, Menou L, Manie S, Schmid-Antomarchi H, Millet M-A, Giuriato S, Ferrua B, Rossi B (1998) Microtubule integrity regulates Src-like and extracellular signal-regulated kinase activities in human pro-monocytic cells. J Biol Chem 273:3394-3400.

Selvaggini C, De Gioia L, Cantu L, Ghibaudi E, Diomede L, Passerini F, Forloni G, Bugiani O, Tagliavini F, Salmona M (1993) Molecular characteristics of a protease-resistant, amyloidogenic and neurotoxic peptide homologous to residues 106-126 of the prion protein. Biochem Biophys Res Commun 194:1380-1386.
Shen Z, Lin C-T, Unkeless JC (1994) Correlations among tyrosine phosphorylation of Shc, p72 syk, PLC- $\gamma 1$, and $\left[\mathrm{Ca}^{2+}\right]_{i}$ flux in Fc $\gamma$ RIIA signaling. J Immunol 152:3017-3023.

Stahl N, Baldwin MA, Teplow DB, Hood L, Gibson BW, Burlingame AL, Prusiner SB (1993) Structural studies of the scrapie prion protein using mass spectroscopy and amino acid sequencing. Biochemistry 32:1991-2002.

Stewart WF, Kawas C, Corrada M, Metter EJ (1997) Risk of Alzheimer's disease and duration of NSAID use. Neurology 48:626-632.

Suck RWL, Krupinska K (1996) Repeated probing of Western blots obtained from Coomassie brilliant blue-stained or unstained polyacrylamide gels. Biotechniques 21:418-422.

Tagliavini F, Prelli F, Verga L, Giaccone G, Sarma R, Gorevic P, Ghetti B, Passerini F, Ghibaudi E, Forloni G, Salmona M, Bugiani O, Frangione B (1993) Synthetic peptides homologous to prion protein residues 106-147 form amyloid-like fibrils in vitro. Proc Natl Acad Sci USA 90:9678-9682.

Tannenbaum CS, Hamilton TA (1989) Lipopolysaccharide-induced gene expression in murine peritoneal macrophages is selectively suppressed by agents that elevate intracellular cAMP. J Immunol 142:1274-1280.

Turner RS, Suzuki N, Chyung ASC, Younkin SG, Lee VM-Y (1996) Amyloids $\beta 40$ and $\beta 42$ are generated intracellulary in cultured human neurons and their secretion increases with maturation. J Biol Chem 271:8966-8970.

Vonakis BM, Chen H, Haleem-Smith H, Metzger H (1997) The unique domain as the site on Lyn kinase for its constitutive association with the high affinity receptor for IgE. J Biol Chem 272:24072-24080.

Williams A, Lucassen PJ, Ritchie D, Bruce M (1997) Prp deposition, microglial activation, and neuronal apoptosis in murine scrapie. Exp Neurol 144:433-438.

Williams AE, Lawson LJ, Perry VH, Fraser H (1994) Characterization of the microglial response in murine scrapie. Neuropathol Appl Neurobiol 20:47-55.

Wood J, Zinsmeister P (1991) Tyrosine phosphorylation systems in Alzheimer's disease pathology. Neurosci Lett 121:12-16.

Wood PL (1994) Differential regulation of IL- $1 \alpha$ and $\mathrm{TNF} \alpha$ release from immortalized murine microglia (BV-2). Life Sci 55:661-668. 